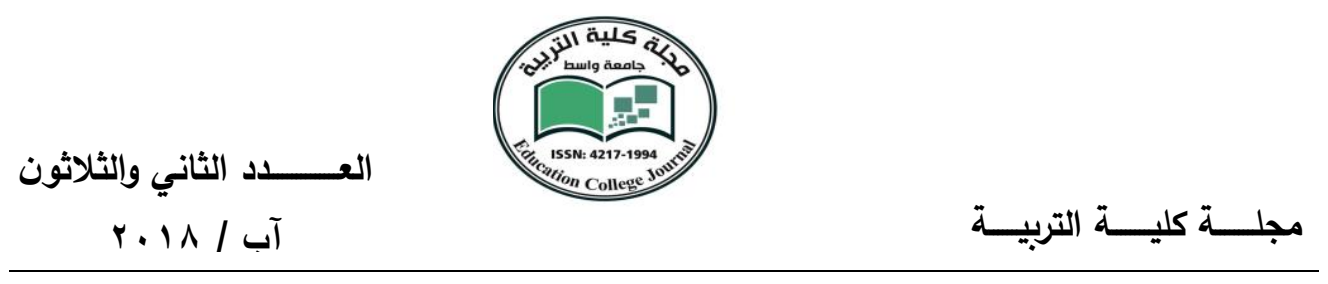

\title{
الرحم البديل بين الاباحة والتحريم في ضوء القواعد الثرعية
}

1.د سلام خليل علوان الموسوي

\section{وزارة التربية العراقية}

\section{d.salam.kh@gmail.com}

ملخص البحث

ان الحمل بالرحم البديل هو تلقيح بيضة المرأة بحيمن الرجل تلقيحا خارجيا في وعاء اختبار ثم زرع هذه البويضة الملقحة في رحم أي امرأه أخرى تقوم بحمله حتى ولادة الجنين سواء أكان الحمل بإرادتها أو بالإكراه

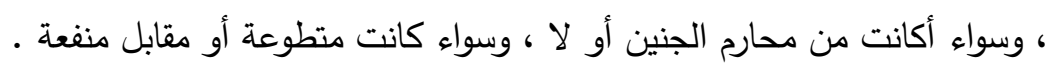

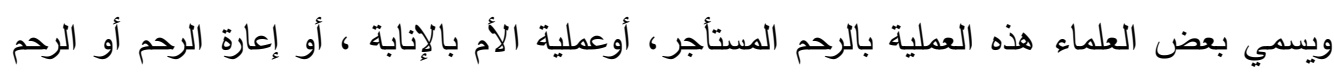

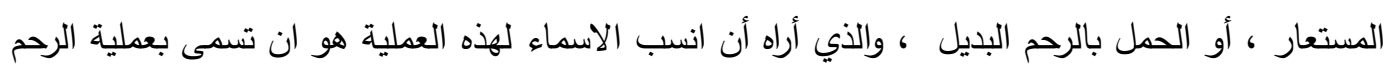

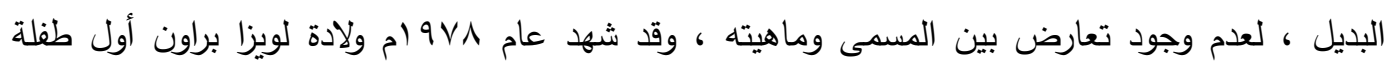

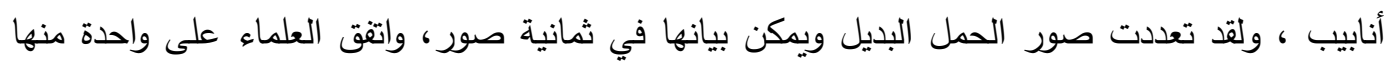
وهي جواز الاخصاب عن طريق تلقيح بويضة الزوجة بماء الزوج في حياتها تلقيحا خارجيا ثم إعادة لتاديه اللقيحة الى رحم الزوجة بشرط وجود التقة بعدم التلاعب في هذه العملية وإدخال طرفا خارجيا شريكا في لري

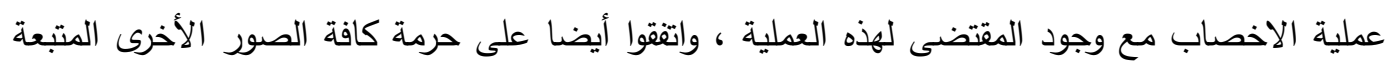

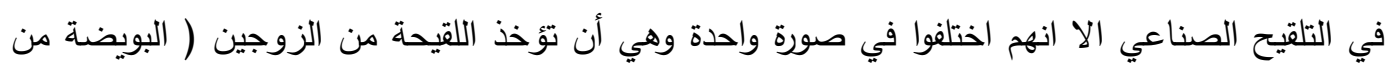

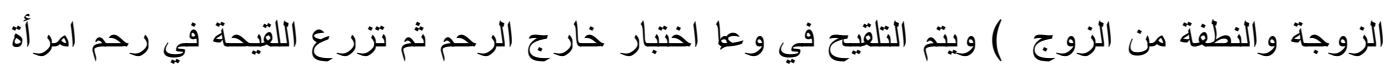

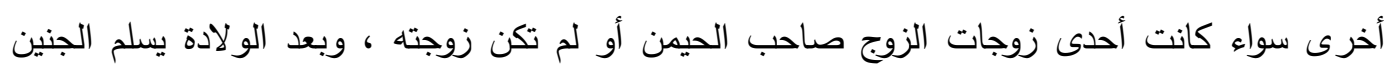

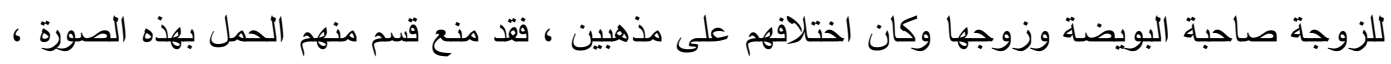

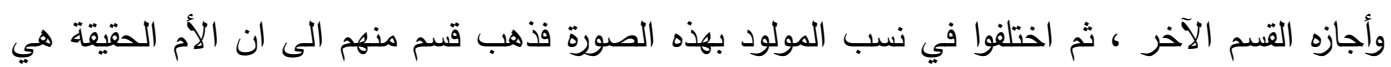




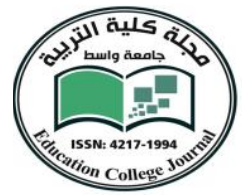

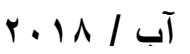

$$
\begin{aligned}
& \text { صاحبة البيضة وهو الراجح ، وذهب القسم الآخر الى ان الام الحقيقية هي صاحبة الرحم التي حملت }
\end{aligned}
$$

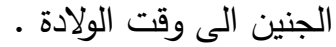

$$
\begin{aligned}
& \text { واختلفوا أيضا في نسبه من جهة الأب ، فذهب بعض العلماء إلى أن المولود ينسب إلى أبيه - زوج } \\
& \text { صاحبة البويضة - الذي لقحت بويضتها بمائه ، ولا ينسب إلى زوج صاحبة الرحم ، وذهب فريق آخر } \\
& \text { إلى أن نسب المولود من ناحية الأب هو لزوج صاحبة الرحم ، والقول الأول هو الراجح • } \\
& \text { Substitution Uterus Between Permission A Substitution Uterusnd } \\
& \text { ProhibitionIn The light of The Legitimate Rules }
\end{aligned}
$$

Prof. Dr .Salam Khalil Alwan Al Moussawi

Conclusion

The supstitutional pregnancy is to fertilize a woman's egg with the sperm of a man who is vaccinated externally in a test container and then fertilize the fertilized egg in the Uterus of any other woman who carries it to the birth of the fetus, either by voluntary or coerced pregnancy, whether it is a fetus or not

Some scientists call this process a lethargy, pregnancy, pregnancy, uterine Uterus, or supstitutional Uterus pregnancy, which $I$ see as the most appropriate name for this process is called the process of uterus supstitutional, because there is no conflict between the name and its meaning,If the science will reach to manu fucture An external uterus is able to incubate the fetus at all stages, and the word Substitution Uterus includes all the elements that lead to reproduction are the sperm, egg and uterus

The idea of Substitution Uterus arose as a result of IVF, as a means of treating infertility among those unable to conceive in normal ways. The various images of uterus variant can be shown in eight pictures and each of these images has a provision of its own in terms of prevention or legal permission 
العــــــــد الثاني والثلاثون

$$
\text { آب / }
$$

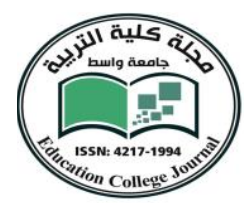

The scholars differed concerning the ratios of the newborn in terms of the mother in the case of pregnancy with the supstitutional uterus. Some of them went to the fact that the mother is the owner of the egg, and the other part went to the fact that the real mother is the owner of the uterus and the first openion is the most likely .

The scholars differed that the child is attributed to his father - the husband of the egg woman - who was vaccinated with his liquid and is not attributed to the husband of the owner of the uterus. Although there is no genetic relationship between them, and does not follow the husband's semen, and the first is the most likely .

\section{المقدمة}

الحمد الله رب العالمين الذي خلق الأنسان من سلالة من طين وأصلي وأسلم وأبارك على النبي الأمين وعلى آله الطيبين وصحبه الغر الميامين . : أما بعد

فان الله تعالى خلق الأنسان وجعله خليفة في الأرض ، ومنحه كل النعم الظاهرة منها والباطنة ولكي

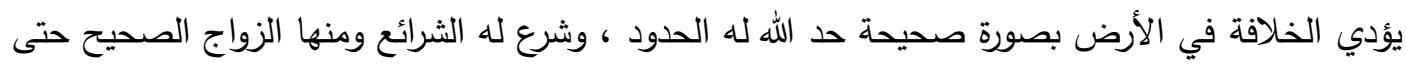
يتناسل ويتكاثر ويعبد الله على أحسن حال ، لتستقر حياته ويعيش بسلام وسكينة ، وعلى الأنسان أن يلتزم بما شرعه الله له في الزواج حتى لا تتقع الأرحام وتختلط الأنساب ، الا أنه مع تطور العلم أكتثف العلماء أسرارا كثيرة وتمكنوا من تخصيب البويضات الأنثوية بالحيامن الذكرية في أنابيب خاصة خارج رحم المرأة ثم استطاع أن يخطوا خطوات سريعة وجديدة في الاستيلاد الاصطناعي ، ومنها طريقة الحمل بالرحم البديل أو المستأجر التي تمكن فيها أستخدام رحم امرأة لحمل لقيحة مكونة من نطفة رجل وبويضة امرأة أخرى مدة الحمل وتسلمه الى الزوجين بعد الوضع ويكون ولدا قانونيا لهما . 
العــــــــد الثاني والثلاثون

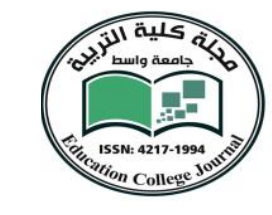

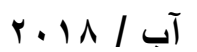

وبما أن المقصد العام من التشريع الإسلامي هو دره المفاسد وجلب المصالح ولتحقيق هذا المقصد بما

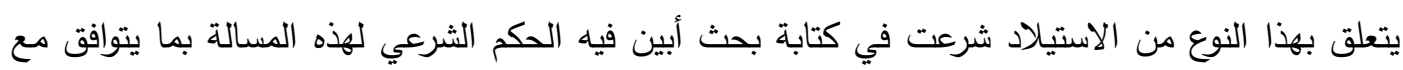
القواعد الثرعية ، ولأن لهذه العملية صورا مختلفة فأني قد أقتصرت الكتابة على صورة واحدة لكونها أقرب الصور الى الاباحة ، وهي أن تؤخذ اللقيحة من الزوجين ( البويضة من الزوجة والنطفة من الزوج ) ويتم التلقيح في وعظا اختبار خارج الرحم ثم تزرع اللقيحة في رحم امرأة أخرى ، وبعد الولادة يسلم

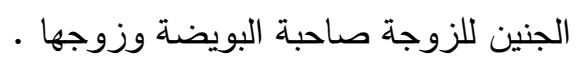

وقد سبقتي كثير من الدراسات على هذا الموضوع منها : اجارة أرحام النساء في الفقه الإسلامي والفقه الوضعي ، للدكتور عبد الله يوسف إبراهيم ، ، وكتاب وسائل الانجاب الصناعية للسيد محم رضا السيستاني ، وبحث الاخصاب خارج الجسم مع استئجار الرحم ، للدكتور ماهر حامد الحولي ، وبحث التلقيح الصناعي

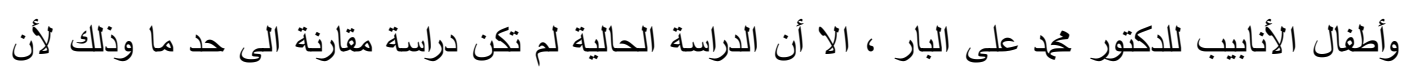
الباحث حاول بها ربط الأدلة والأقوال بالقواعد الثرعية كما هو واضح في عنوان البحث .

وقسمت البحث على مقدمة وتمهيد وثلاثة مباحث ، تكلمت في المبحث الأول على مفهوم الحمل في الرحم البديل ونشأته وصوره ، وتكلمت في المبحث الثاني على موقف العلماء من الرحم البديل ، أما المبحث الثالث فقد كان في نسب المولود بالرحم البديل ، وثم ختمت البحث بخاتمة ، وقائمة للمصادر والمراجع ، وملخصا باللغة الأنجليزية ، وفي الختام أسأل الله العلي العظيم أن يكون عملي هذا خالصا لوجهه الكريم ، وما التوفيق الا من عند الله .

تمهيد

ان الله تعالى خلق البشر من نفس واحدة بعد أن خلق منها زوجها وبث منهما رجالا كثيرا ونساء ، وقد بين الله تعالى لنا خلق الانسان اذ يبدأ الحمل منذ التقاء الحيوان المنوي للرجل مع بويضة المرأة في الأيام التي تكون فيها المرأة قادرة على افراز بويضة ناضجة تخرج من المبيض وتتقدم في قناة خاصة تلتقي بها مع ملايين الحيوانات المنوية الذكرية فيتمكن واحد من هذه الحيوانات من اختراق جدار البيضة وتخصيبها فتتكون خلية البيضة المخصبة ثم تتقسم بصورة سريعة الى عدد من الأقسام 
العـــــــد الثاني والثلاثون

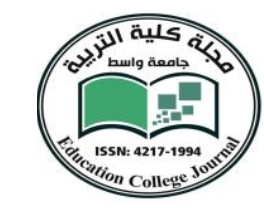

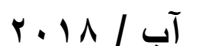

مجلــــة كليـــة التربيـــة

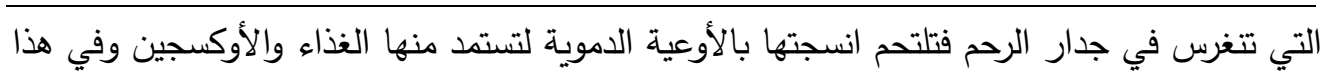

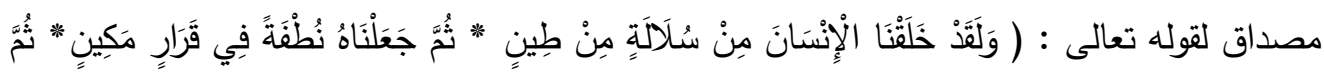

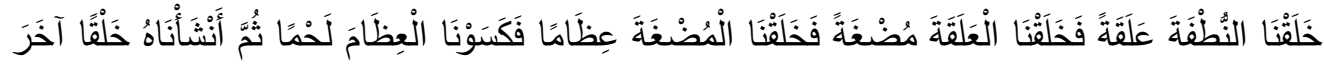

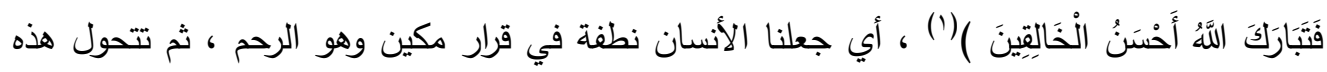

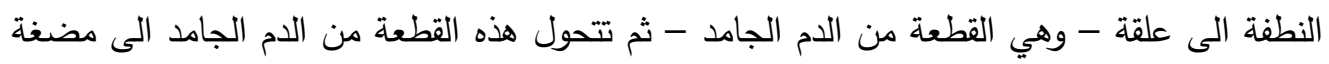

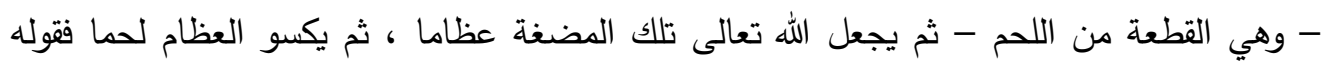

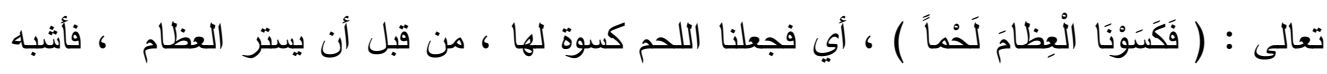

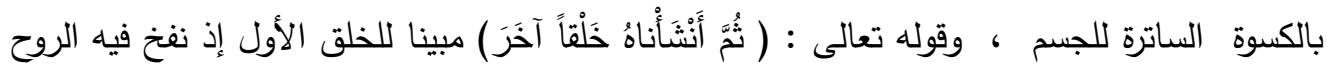
وجعله حيوانا بعد ما كان أشبه بالجماد ، ناطقا سميعا بصيرا.

وهذه العملية المعقدة تحتاج الى ظروف خاصة بها لا تتم الا بعناية الله عز وجل ، وتتاسب ثرة

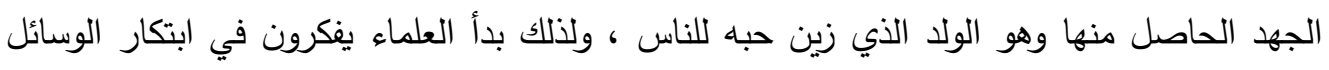

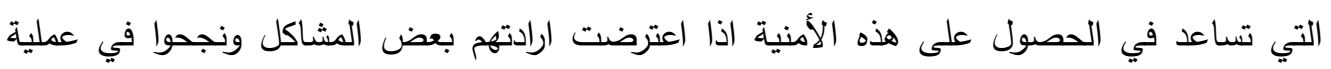

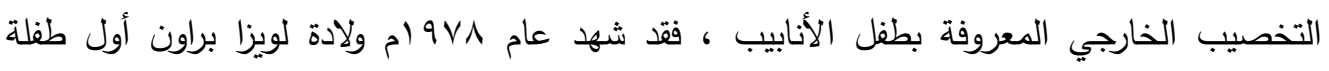

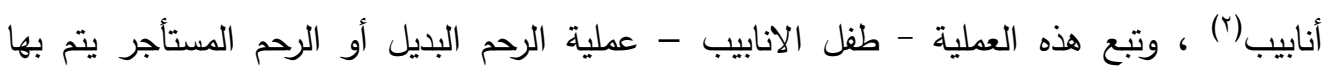

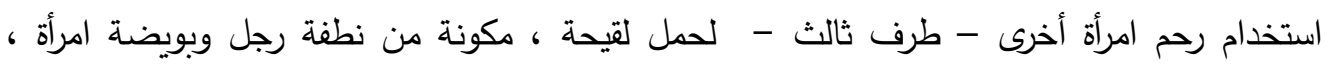

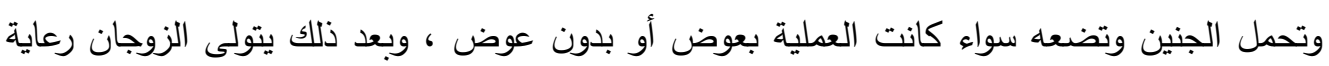

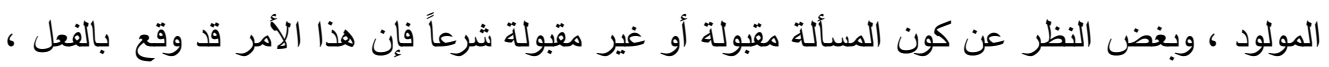

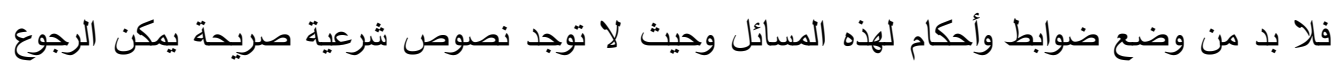

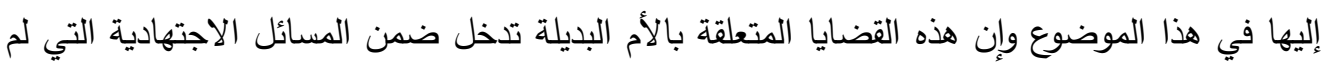

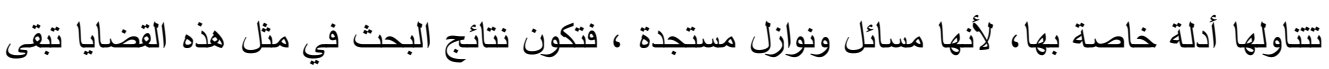

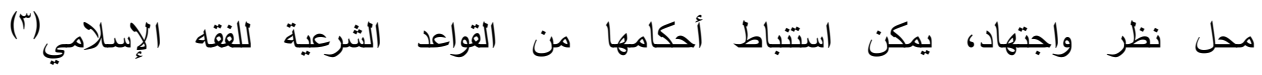




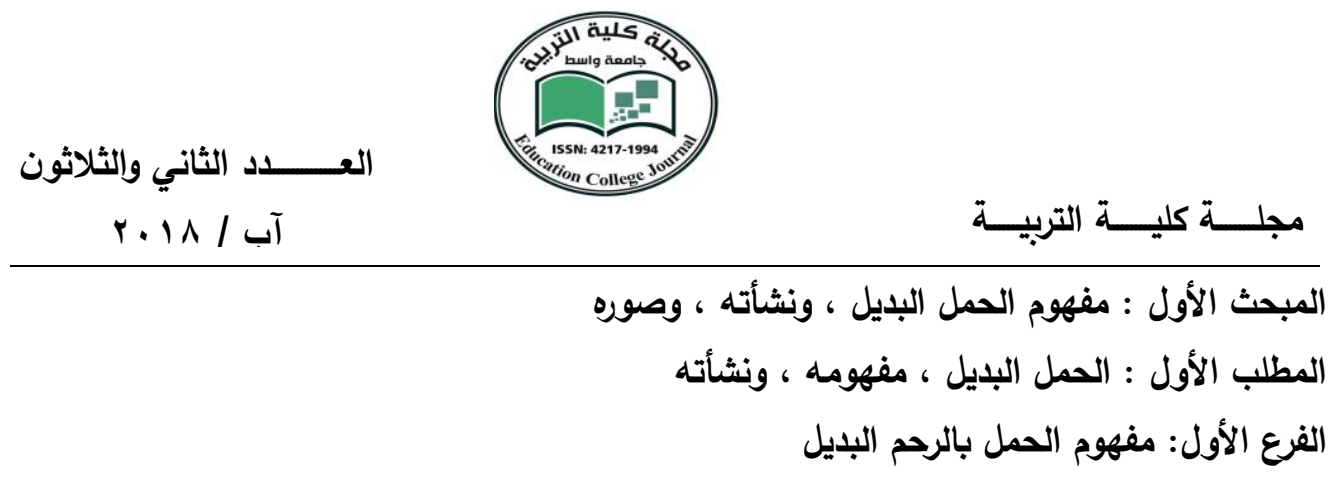

الحمل بالرحم البديل هو تلقيح بيضة المرأة بحيمن الرجل تلقيحا خارجيا في وعاء اختبار ثم زرع هذه البويضة الملقحة في رحم أي امرأه أخرى تقوم بحمله حتى ولادة الجنين سواء أكان الحمل بإرادتها أو بالإكراه ، وسواء أكانت من محارم الجنين أو لا ، وسواء كانت متطوعة أو مقابل منفعة أ).

ويسمي بعض العلماء هذه العملية بالرحم المستأجر، والذي أراه بان هذه التسمية فيها نظر لان المستأجر مأخوذ من الاجارة والاجارة غير متحققة من الناحية الشرعية ولو كانت متحققة لأنتفت الحاجة الى البحث في هذا الموضوع ماحون

وأطلق بعض العماء على هذه العملية عملية الأم بالإنابة وهي تسمية فيها نظر أيضا ، لأن الانابة تكون بين طرفين ، اذ انها إقامة الغير مقام النفس في تصرف جائز معلوم ، والحمل بالإنابة تصرف غير معلوم لأن الجنين يعتبر طرفا ثالثا في العقد وهو لا يمتلك الإرادة في انابة غير الام الثرعية في حمله ، ومن جهة أخرى ان الأم البديلة والابوين لا يمتلكون التصرف فيما يخص الجنين من غذاء وصفات وراثية يمكن ان تتتقل من الأم البديلة(0) .

وقد تسمى هذه العملية عملية إعارة الرحم أو الرحم المستعار وهو إنشاء عقد تبرع مع امرأة على زرع بييضة من امرأة ملقحة بحيوان منوي من زوجها في رحم امرأة أخرى حتى تلد، بدون مقابل مالي ، وهذه التسمية خاطئة لان الإعارة غير محددة ولا تكون بالرحم فقط لأن أغلب أعضاء الجسم تثترك في إيصال الغذاء والأوكسجين الى الجنين وليس مسؤولية الرحم فقط(آ) .

وقد يطلق على هذه العملية اسم الحمل بالرحم البديل وهذه التسمية فيها نظر أيضا ، لأنه توجد ثمانية صور لهذه العملية منها ثلاثة صور تقوم الزوجة بعملية الحمل ، وصورة أخرى تتوب عنها ضرتها في حمل الجنين 


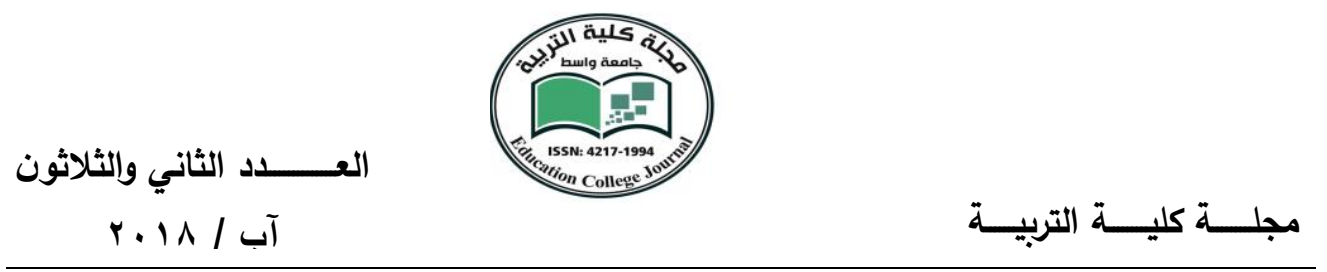

والذي أراه أن انسب الاسماء لهذه العملية هو ان تسمى بعملية الحمل البديل ، لعدم وجود تعارض بين المسمى وماهيته الا اذا توصل العلم الى تصنيع رحم خارجي يتمكن من احتضان الجنين بكافة مراحله ، وكلمة البديل عامة تشمل جميع العناصر التي تؤدي الى الأنجاب - الحيمن والبيضة والرحم - فقد يكون البديل هو الحيمن وهو متحقق في أربعة صور من أصل ثمان صور لهذه العملية ، وقد يكون البديل يدل على البيضة وهو متحقق في أربعة صور أيضا ، وقد يكون البديل بدل الرحم وهو متحقق في خمسة صور

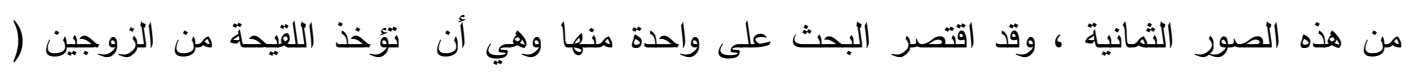
البويضة من الزوجة والنطفة من الزوج ) وتزرع اللقيحة في رحم أمرأة أخرى قد تكون الضرة ، وبهذا ينطبق اسم الحمل بالرحم البديل على موضوع البحث .

الفرع الثاني : نشأة فكرة الحمل البديل

لقد نجح العلماء في زيادة انتاج الحيوانات ذات الصفات الممتازة عن طريق أخذ عدد من البويضات من أنثى حيوان معين ذات صفات ممتازة ثم تخصيبها مختبريا وزرع تلك الأجنة في أرحام عدد من الحيوانات الأخرى العادية ، وبعد النجاح الذي تحقق في عالم الحيوان بدأت عمليات الرحم البديل بين البشر منذ ثانينيات القرن الماضي في عدد كبير من المراكز المنتشرة في كافة انحاء العالم ، ولا سيما في الولايات المتحدة وأوربا ، والعدد في تزايد ويصل معدل الأجرة إلى (17) ألف دولار، وقد أنتجت الوكالات مئات المواليد بهذه الطريقة ، وهكذا تصبح أرحام الفقيرات في بعض الدول بضاعة للبيع والإيجار ، يستغلها الأثرياء والأغنياء بغية الحصول بذلك على أبناء دون عناء وما يتبعها من مشاق وآلام(V) .

وقد نشأت فكرة الرحم البديل نتيجة لعملية الإخصاب الصناعي خارج الرحم ، بوصفها وسيلة لمعالجة العقم لاى غير القادرين على الإنجاب بالطرق الاعتيادية ، اذ أجريت أول عملية إخصاب خارج الرحم بأمريكا سنة 1945م ، ثم توالى إجراء هذه العمليات في جميع دول العالم ، ونتيجة لتطور العلم وعدم تشريع القوانين التي تتظم عملية الحصول على الولا سارع الناس الى تحقيق رغبتهم ولو بتدخل طرف ثالث في العلاقة بينهما ، سواء أكان تدخله بالرحم التي تحمل لقيحة الزوجين ، أو كان بالبويضة التي تُخصب من زوج امرأة

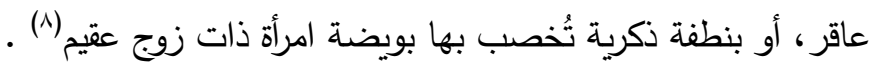




\section{العــــــد الثاني والثلاثون}

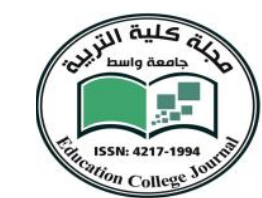

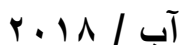

مجلـــة كليـــة التربيـــة

ومع تطور الحمل بالرحم البديل أدت هذه العملية انتاج دوائر لتأجير الأرحام ، والقيام بأعمال السمسرة

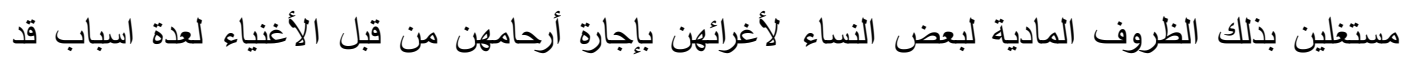

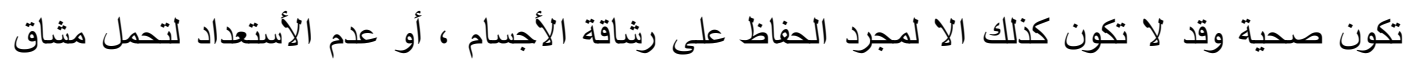

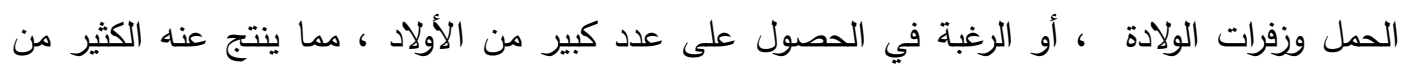

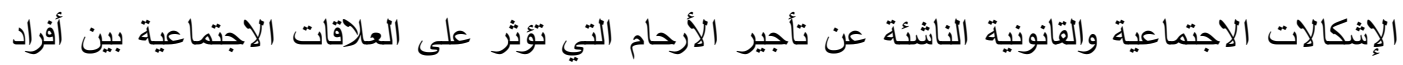

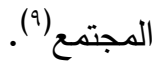

المطلب الثاني : صور الحمل البديل لقد تعددت صور الحمل البديل ويمكن بيانها في ثمانية صور هي :

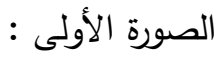

أن تكون اللقيحة من الزوجين ( البويضة من الزوجة والنطفة من الزوج ) ، ويتم التلقيح خارجيا عن

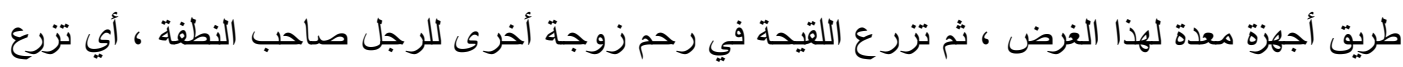

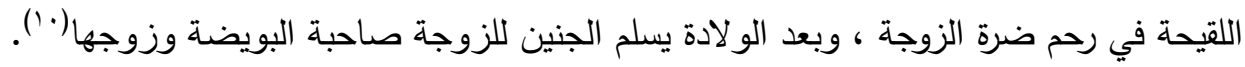

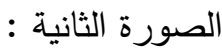

أن تؤخذ اللقيحة من الزوجين ( البويضة من الزوجة والنطفة من الزوج ) ويتم التلقيح في وعا اختبار

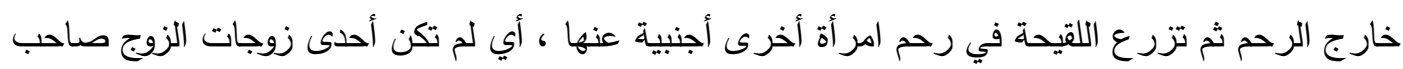

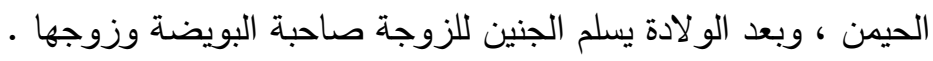

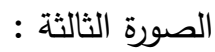

يكون الحيوان المنوي في هذه الصورة من الزوج والبويضة من امرأة أجنبية عنه ، ثم تتنقل البويضة الملقحة إلى رحم الزوجة ، وبعد الو لادة يسلم الجنين للزوج صاحب النطفة وزئل وزوجته التي انجبته. 


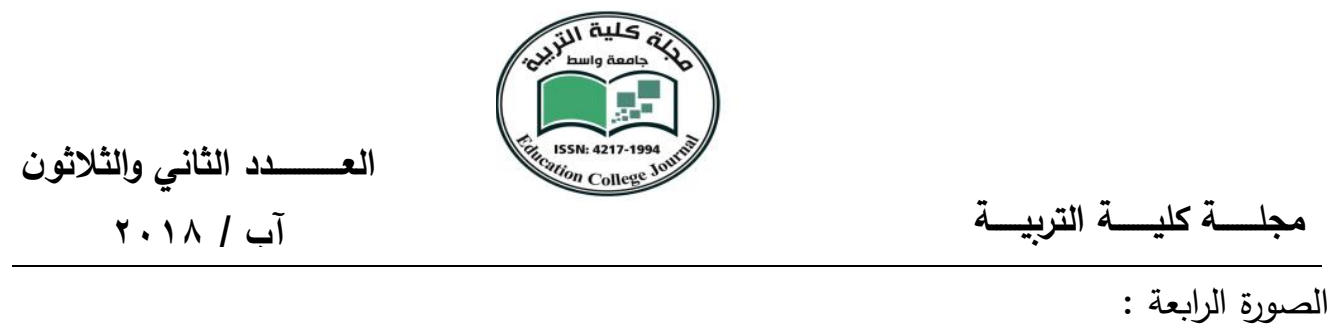

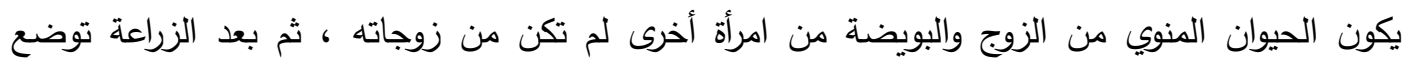

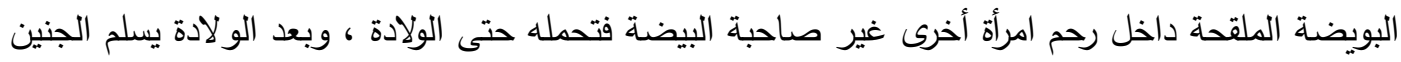

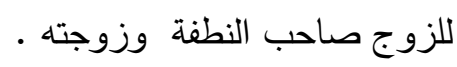

الصورة الخامسة :

يؤخذ الحيوان المنوي من رجل أجنبي عن الزوجة ، والبويضة من الزوجة وبعد التخصيب خارج الرحم ، تتقل

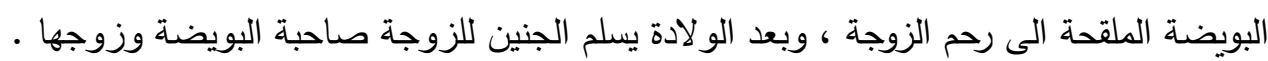
الصورة السادة : أن تؤخذ بويضة الزوجة وتلقح بمط رجل أجنبي ، ثم توضع اللقيحة في رحم امرأة أجنبية وبعد الولادة

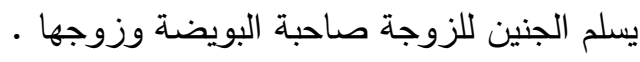
الصورة السابعة :

في تلك الصورة يكون الحيوان المنوي من رجل أجنبي عن الزوجة ، وكذلك البويضة من امرأة أجنبية عن

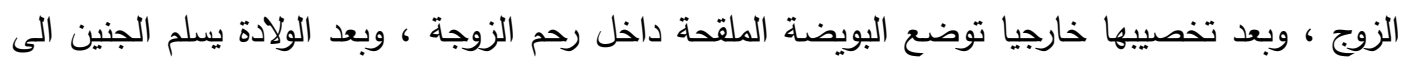
الزوجة التي أنجبته وزوجها ل

الصورة الثامنة :

في تلك الصورة يكون الحيوان المنوي من رجل أجنبي عن الزوجة ، وكذلك البويضة من امرأة أجنبية عن

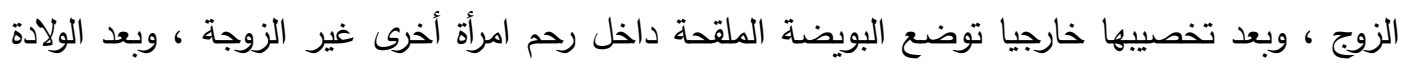

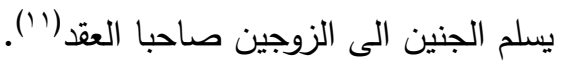




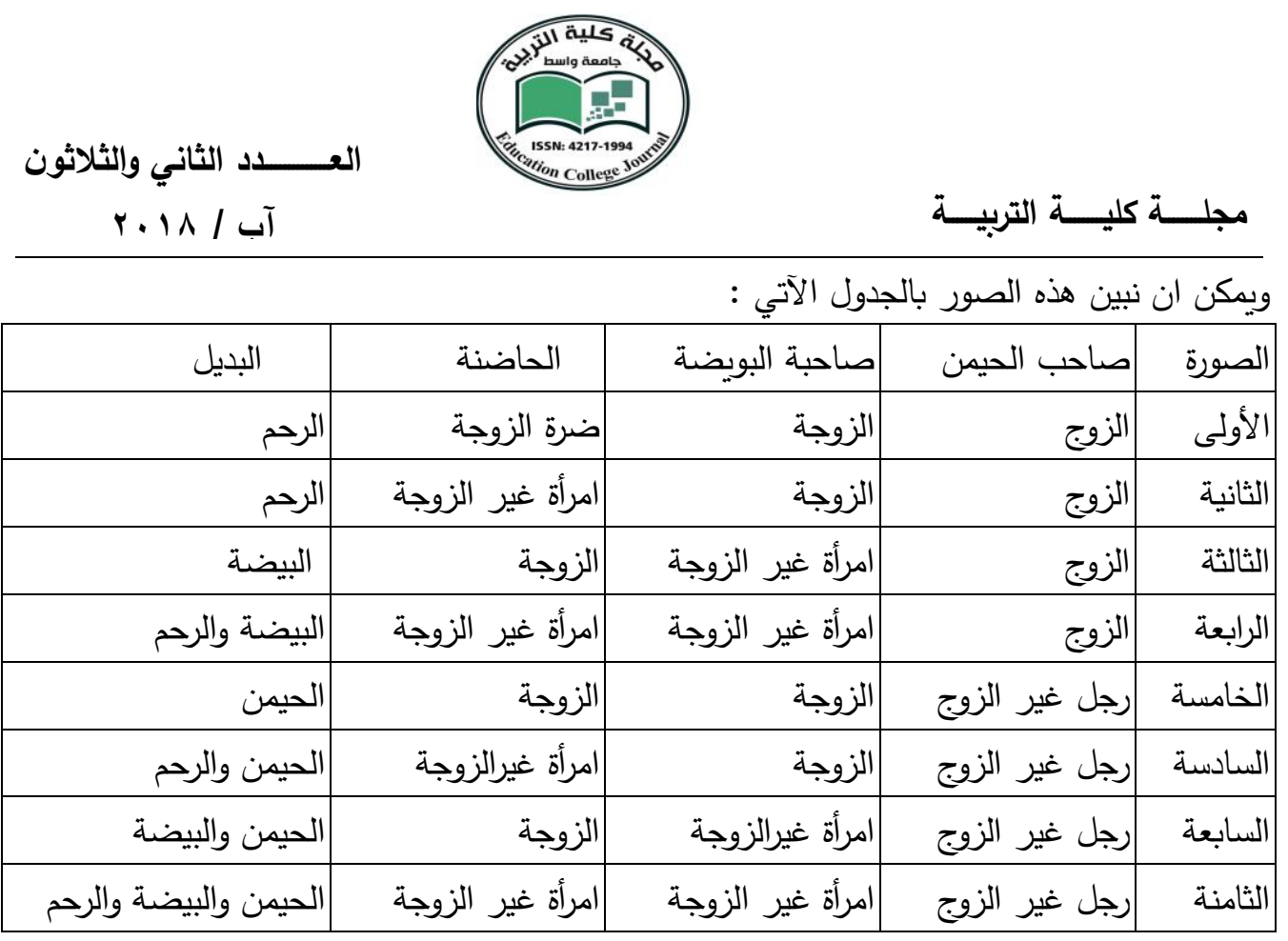




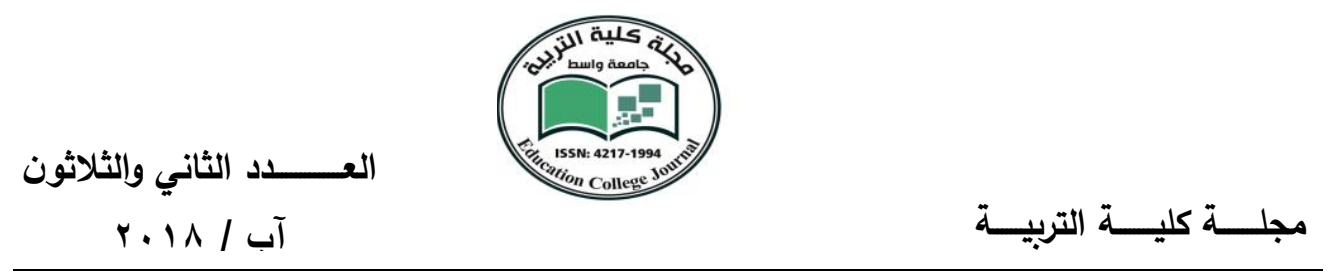

المبحث الثاني : موقف العلماء من الحمل بالرحم البديل

لقد أتقق العلماء على جواز الاخصاب عن طريق تلقيح بويضة الزوجة بماء الزوج في حياتها تلقيحا خارجيا ثم إعادة اللقيحة الى رحم الزوجة بشرط وجود الثقة بعدم التلاعب في هذه العملية وإدخال طرفا خارجيا شريكا في عملية الاخصاب ، واتفقا أيضا على حرمة كافة الصور الأخرى المتبعة في التلقيح الصناعي الا انهم اختلفوا في صورة واحدة وهي أن تؤخذ اللقيحة من الزوجين ( البويضة من الزوجة والنطفة من الزوج ) ويتم التلقيح في وعطا اختبار خارج الرحم ثم تزرع اللقيحة في رحم امرأة أخرى الخى التردي سواء كانت أحدى زوجات الزوج صاحب الحيمن أو لم تكن زوجته ، وبعد الولادة يسلم الجنين للزوجة صاحبة البويضة وزوجها وكان اختلافهم على مذهبين ، فقد منع قسم منهم الحمل بهذه الصورة ، وأجازه القسم الآخر ، وهذه الصورة هي الصورة الوحيدة التي تتاولناها في هذه الدراسة لتوافقها مع عنوان البحث ، لذلك سوف نوزع دراستتا في هذا المبحث على ثلاثة مطالب ، نتكلم في المطلب الأول على أدلة المانعين للحمل بالرحم البديل ، أما المطلب الثاني فسوف يتناول أدلة المجوزين للحمل بالرحم البديل ، أما المطلب الثالث ففي مناقشة أدلة الفريقين وبيان الراجح منها ، وكما يأتي . المطلب الأول : أدلة المانعين للحمل بالرحم البديل

ذهب قسم من العلماء الى حرمة الحمل بالرحم البديل ، والى هذا القول ذهب جمهور العلماء ، وبهذا قرر المجمع الفقهي الإسلامي التابع لرابطة العالم الإسلامي ، وهذا ما رجحه مجمع الفقه الإسلامي التابع لمنظمة المؤتمر الإسلامي ، وهو رأي أغلب العلماء واليه ذهب الثيخ عطية صقر والدكتور البوطي ، وهو المفتى به

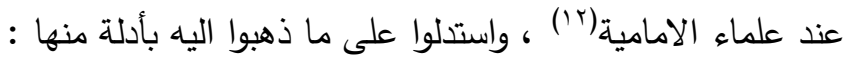

الدليل الأول :

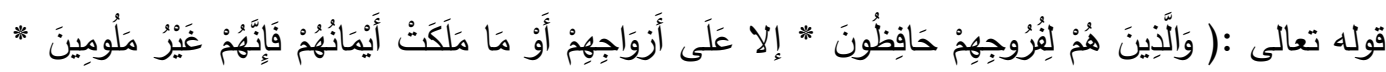

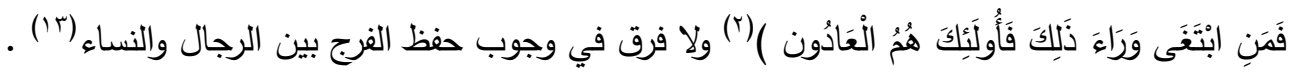


العـــــــد الثاني والثلاثون

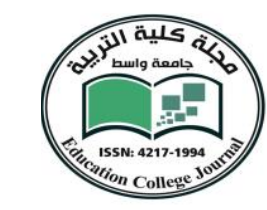

آب / 1 الب

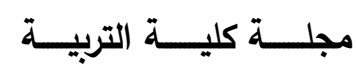

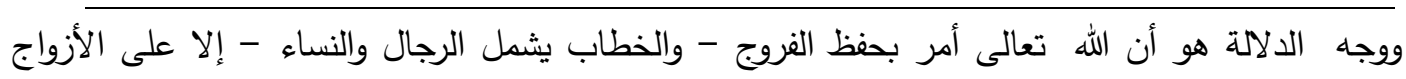

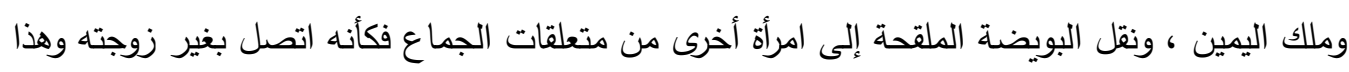

من المحظور لأن ذلك من حق الأزواج فقط(؛) لأن الزوج بعقد الزواج له التصرف بما في الرحم على أن لا

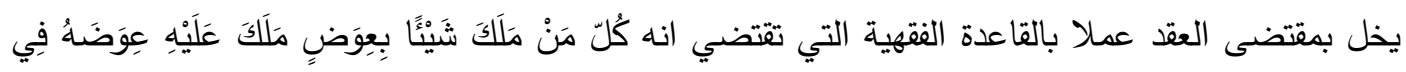

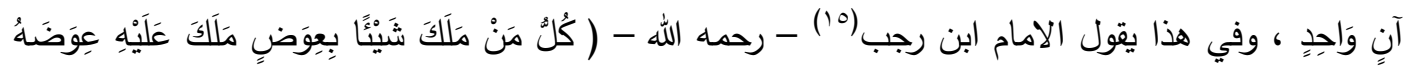

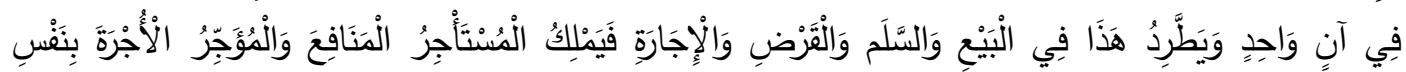

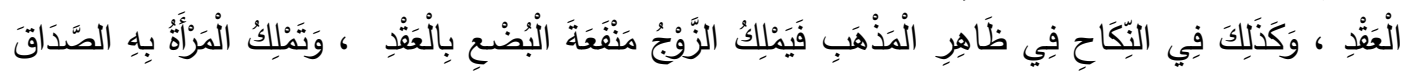
كُلَّلَهُ (17)

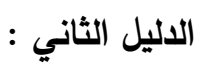

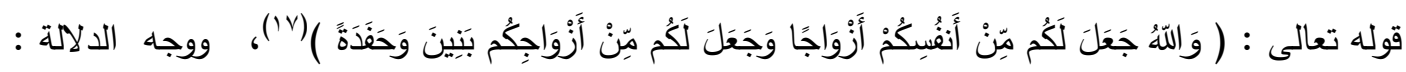

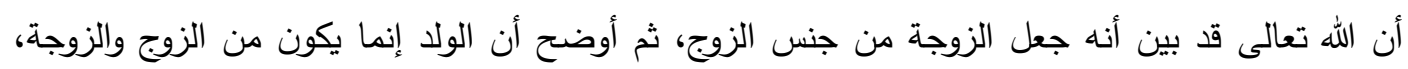

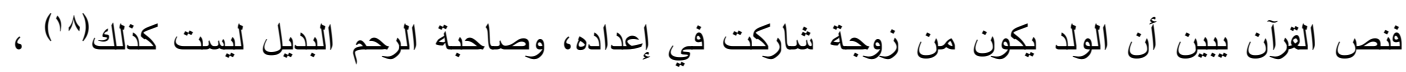

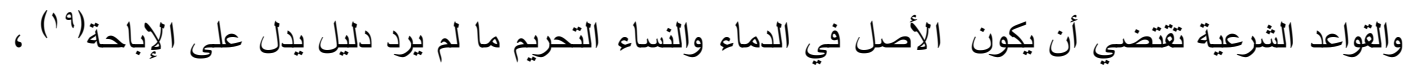

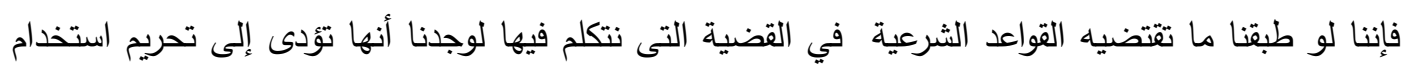

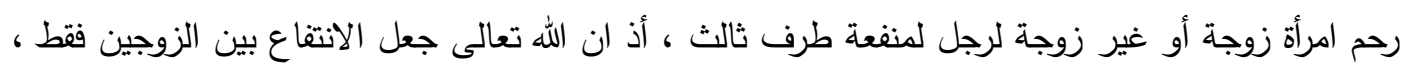

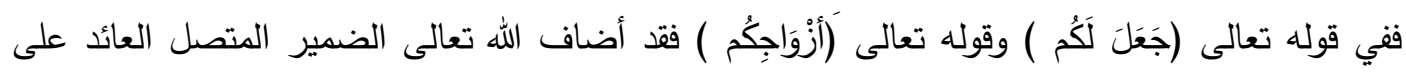

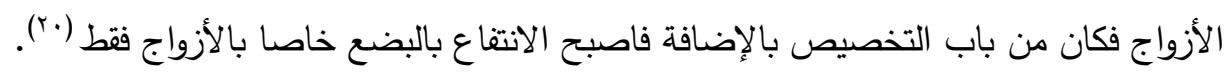

الاليل الثالث :

وجود شبهة اختلاط الأنساب؛ لاحتمال أن تفشل عملية التلقيح بعد وضع اللقيحة في الرحم المؤجر، ويحدث

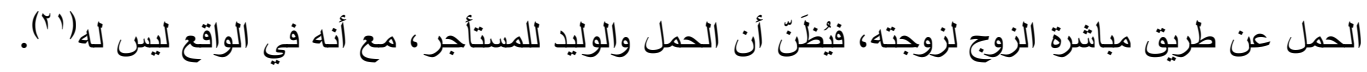


العـــــــد الثاني والثلاثون

آب /

وكذلك ترد هذه الشبهة في حالة استمرار الزوج في مباشرة زوجته وهي حاملة للبويضة الملقحة؛ لأن الجنين يتغذى بماء الزوج، كما يتغذى من الأم الحامل وهذا لا يجوز شرعا عملا بالقاعدة الفقهية ( ملك الحل لا لإه يحتمل الثركة ، والنكاح لا يحتمل الاشتراك )(rr(r)، وقد ورد النهي الصريح عن وطء الحامل التي هي من

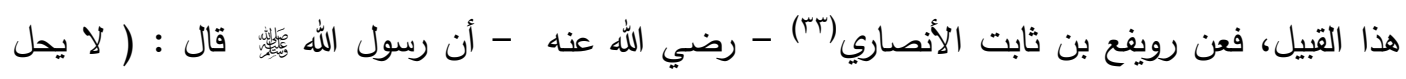

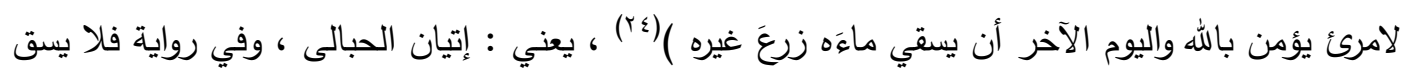
ماءه ولا غيره

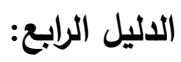

أن الحمل بهذه الطريقة مستلزم لانكثاف عورة المرأة ، والنظر إليها، ولمسها، والأصل في ذلك أنه محرم شرعًا، لا يجوز إلا لضرورة ، ولا ضرورة هنا ، ولو سلمنا بوجود الضرورة فإنها بحق صاحبة البيضة لأنها

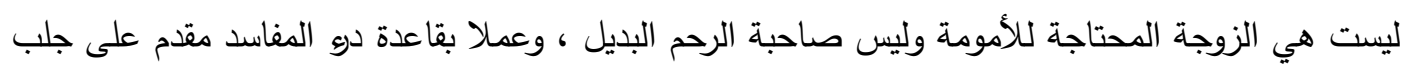
المصالح اقتضى التحريم لوجود المفسدة الظاهرة مع عدم وجود الضرورة لذلك الفعل(ro) .

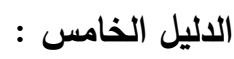

أن استبدال الأرحام يترتب عليه مفاسد كثيرة لأنه يؤدي إلى اختلاط الأنساب، إذا كانت المستأجرة متزوجة، فتحصل المنازعات بين الأم صاحبة البويضة، وصاحبة الرحم، والإسلام قد حرم كل ما يؤدي إلى النزاع والخلاف ن وأنه يفسد معنى الأمومة الحقيقية للمرأة التي فطرها الله عليها، إذ غاية ما هنالك إقرار بويضة بدون عناء ولا مشقة، بينما التي حملتها عانت آلام الحمل وتغذى بغذائها حتى غدا بضعة منها ، وأن فتح هذا الباب يؤدي إلى أن تسلكه كل امرأة ثرية، أرادت أن تحافظ على صحتها ورشاقة بدنها، بل قد تتجب في السنة عدداً كبيراً من الأولاد ويتحول الإنجاب بهذه الطريقة إلى مفاخرة ومتاجرة ، وكذلك أن ممارسة إجارة الأرحام يفقد المرأة كرامتها وتصير كالدابة المستأجرة للاستخدام حسب الطلب ، وتصبح التجارة في بدنها

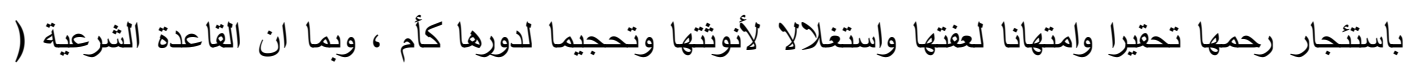

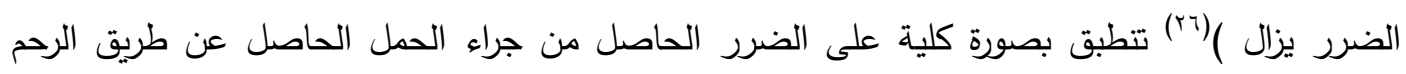
البديل لذلك تحرم هذه المسألة بكل صورها(rV) . 


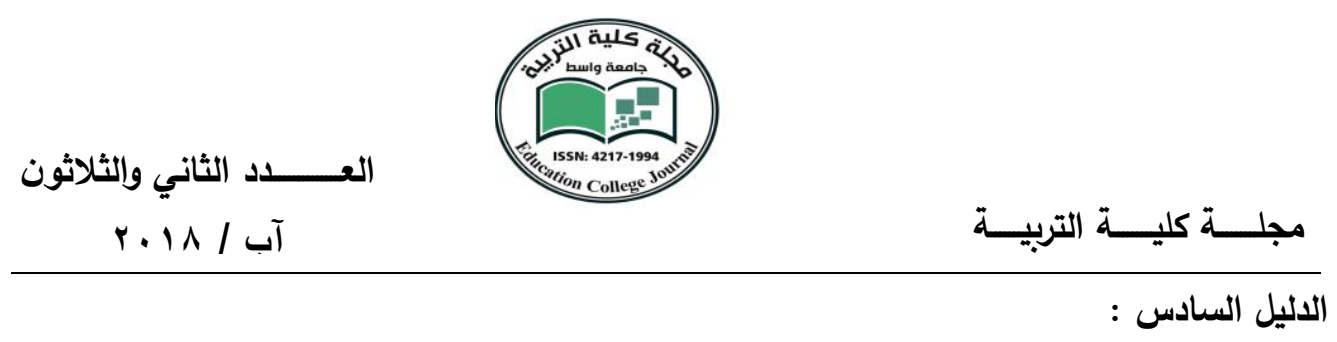

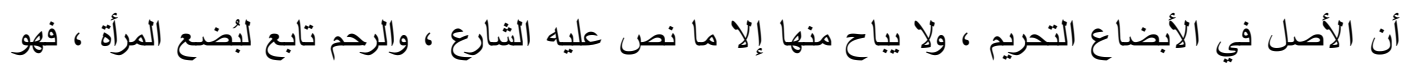

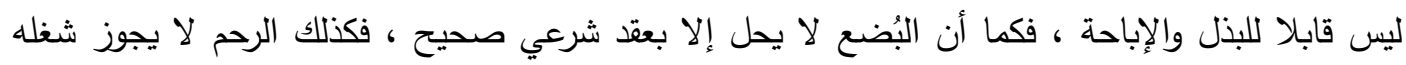

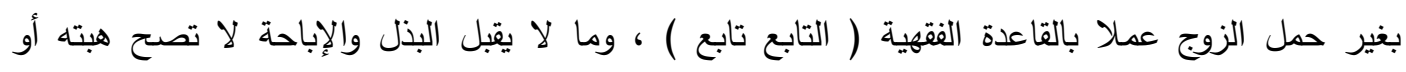
اجارته(rᄉ)

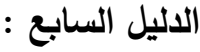

حرم الشرع كل أمر يؤدي إلى حدوث الخلاف والنزاع بين الأفراد أو الجماعات؛ ولهذا وجدنا أن كثيرًا من

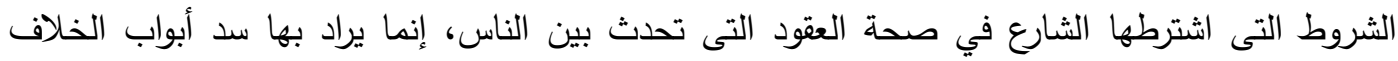

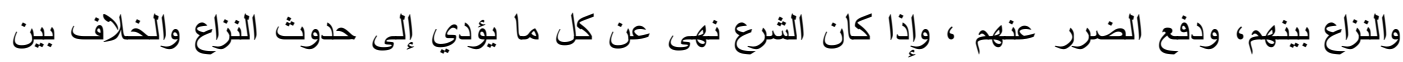

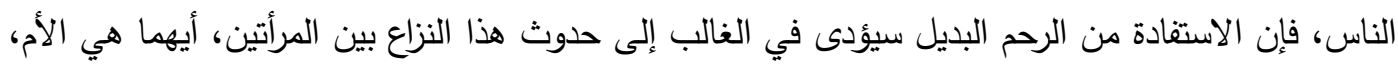

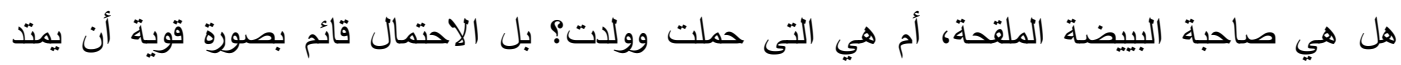

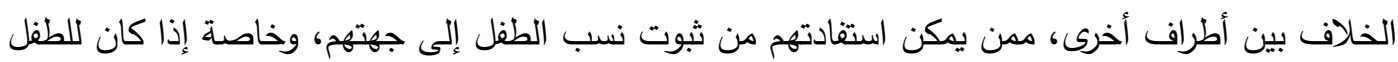

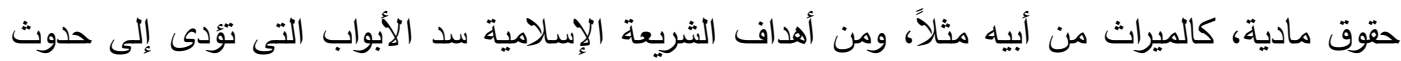

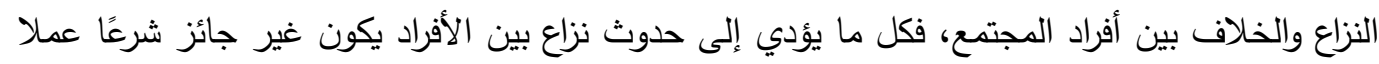

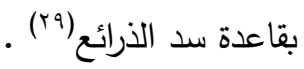

\section{المطلب الثاني : أدلة المجوزين للحمل بالرحم البديل}

ذهب بعض العلماء الى جواز الحمل بالإنابة عندما تؤخذ اللقيحة من الزوجين - - البويضة من الزوجة

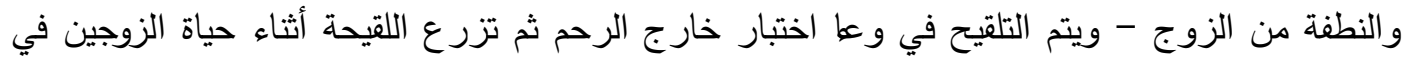

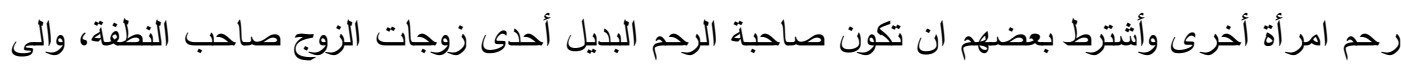

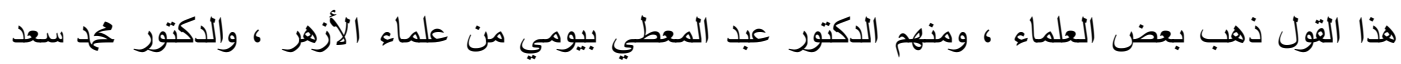




\section{العــــــد الثاني والثلاثون}

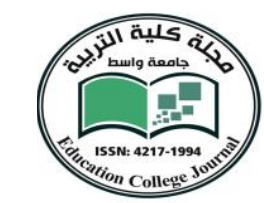

مجلــة كليـــة التربيــة الدين حافظ ، والدكتور إسماعيل برادة ، واليه ذهب قسم من علماء الامامية (·r)، واستدلَّ أصحابُ هذا القول

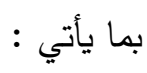

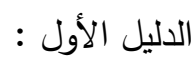

وجود حالة الحاجة الثرعية حيث يلجأ لهذه الطريقة عند وجود أسباب طبية تمنع المرأة من الحمل ، كأن تولد

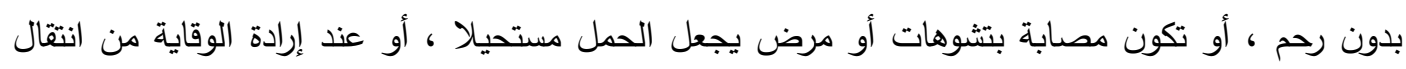

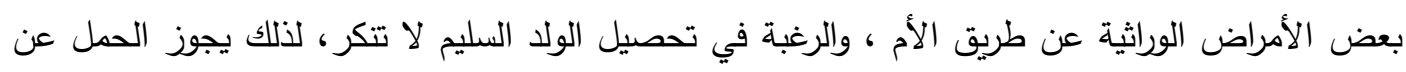

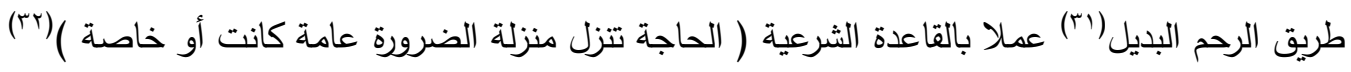

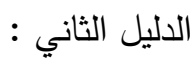

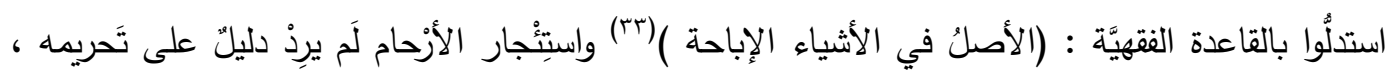
فيُجرى على الأصل العام ، وهو الإباحة (أُج).

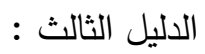

استذلوا بقياس الرحم على الثذي بجامع التغذية في كلٍ منهما ، فكما تتم التغذية عن طريق الفم في

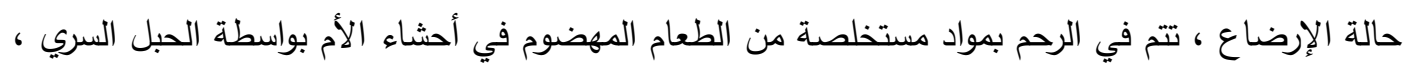

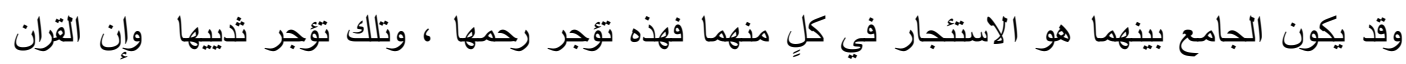

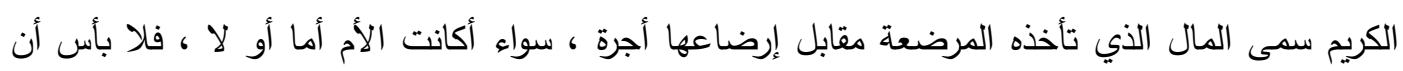

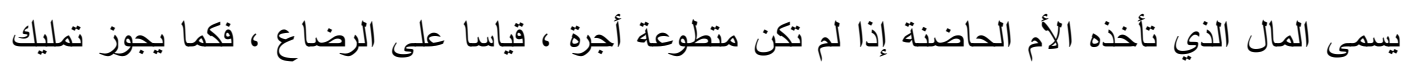

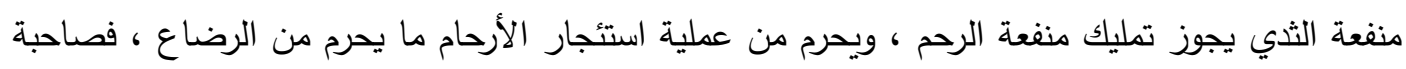

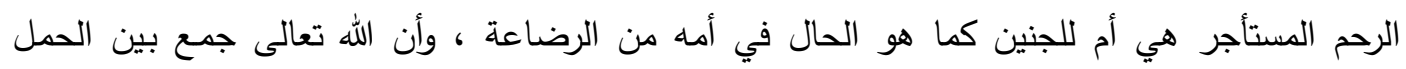

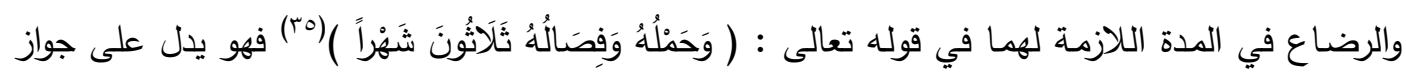

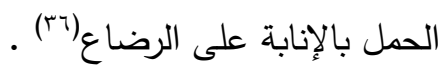




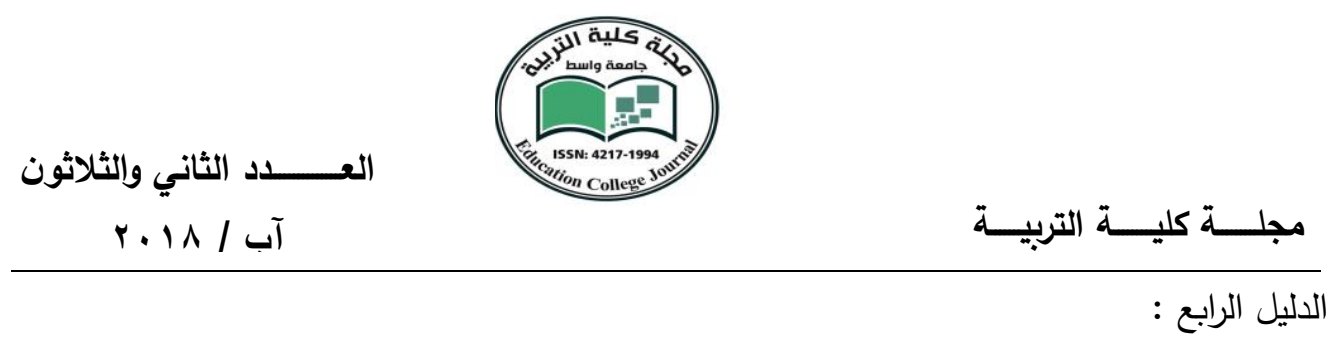

تصريح علماء الطب انه حينما تتحد البويضة مع الحيوان المنوي الذكر يتم التزاوج بين 23 كروموسوما منفردا من البيضة و 23 كروموسوم منفردا من الحيوان المنوي ،ليتكّون لدينا 23 كروموسوما ثنائيا ، وتصطف الجينات الوراثية لكل نوع من الخواص على الكروموسومات الثنائية متقابلة مع بعضها البعض في ترتيب تتابعي متكامل ، حيث يوجد جين واحد من الأم في مقالبه جين واحد من الأب ، وكل جينيين معا يحمان معا انتقال خاصية وراثية إلى الكائن الجديد، وبناءاً على هذا فإن التشكيل الوراثي للجنين يكون للزوج صاحب الحيوان المنوي وزوجته صاحبة البويضة ، والبويضة الملقحة من الزوج لا يمكن تلقيحها مرة أخرى بأي حيوان منوي أخر غير الذي لقحت به في البداية ، فالرحم لا ينقل أي صفة وراثية ولا يسهم بأي تكوين جيني ، إنما هو يمد الطفل بالغذاء والأوكسجين والأمشاج الرحمية ، ولا يمكن أن يكون اختلاط بالأنساب لعدم إمكانية تلقيح البويضة الملقحة مرة أخرى(؟rان.

الاليل الخامس

إن صورة الرحم البديل فيها معنى الزوجية ، لان فيها عقد قائم على إيجاب وقبول، شهود، أجرة، ومنفعة وهي حمل الجنين تسعة أشهر، ويتم الإعلان عن هذه العملية، فهي ليس فيها وطء محرم ولا تعد زنا وليس فيها حتى شبهه زنا ، لان الزنا يقوم على الوطء المحرم وهذه العملية تخلو من الوطء ، فإذا كانت هذه

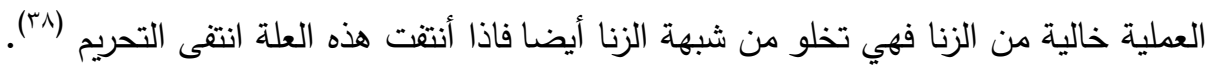

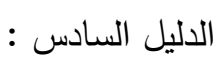

ان بعض الآيات القرآنية الكريمة التي تتحدث عن المحرمات مثل قوله تعالى : \} حُرِّمَتْ عَلَيْكُمْ أُمَّهَاتُكُمْ

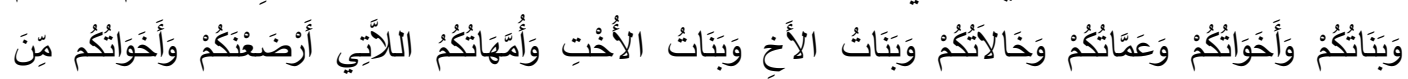

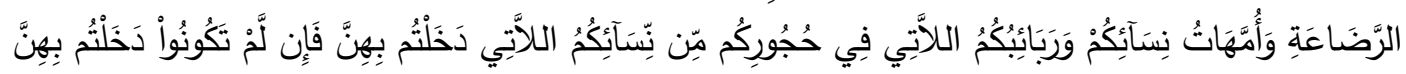

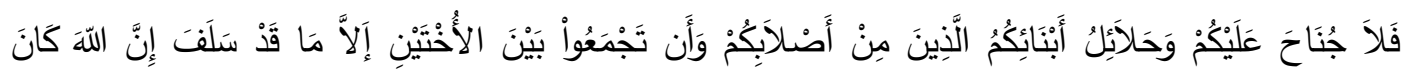

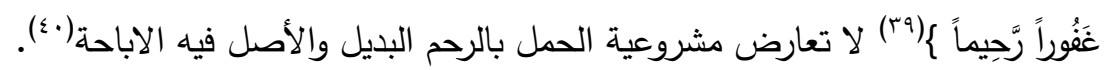




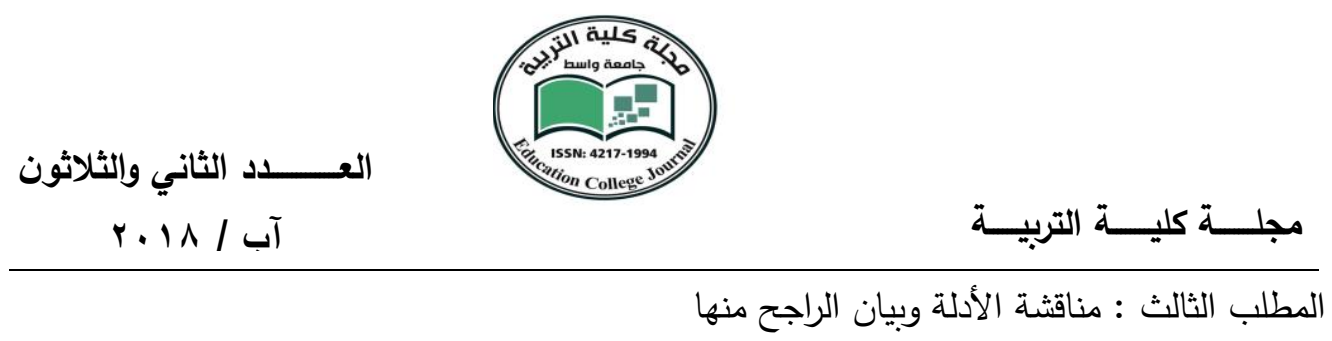

ان القول الراجح والله أعلم هو القول الأول - تحريم الحمل بالإنابة - لقوة الأدلة التي استدل بها

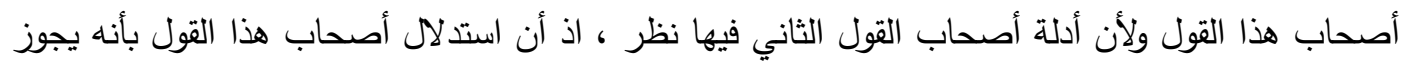

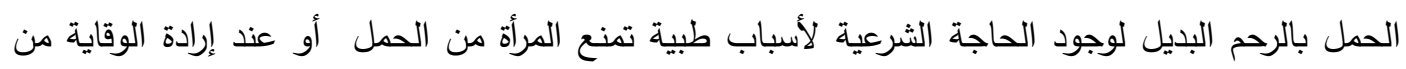

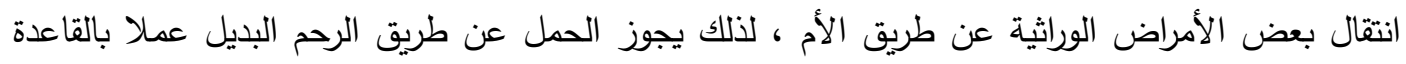

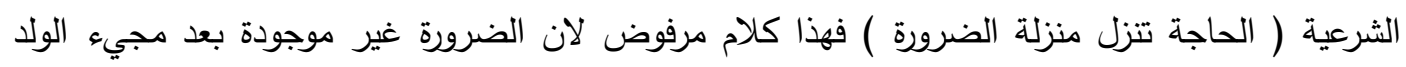

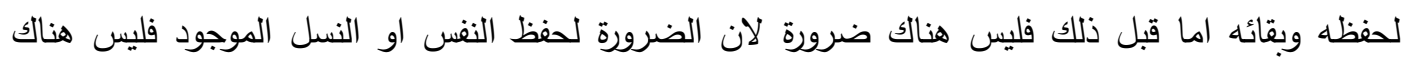

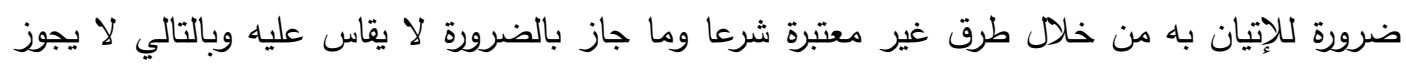

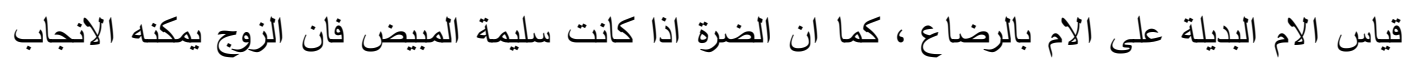

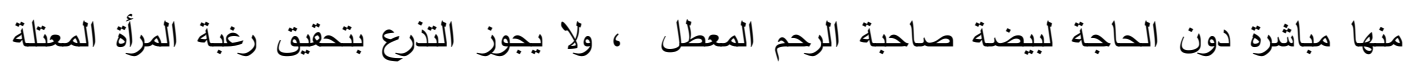

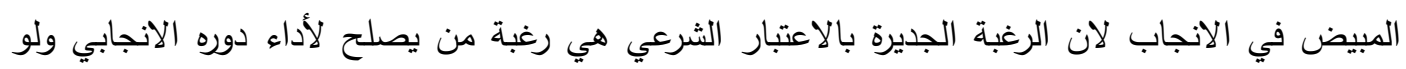

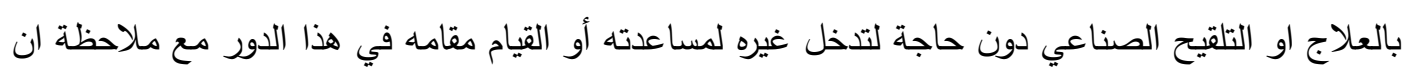

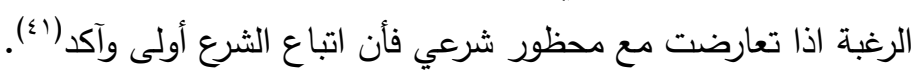

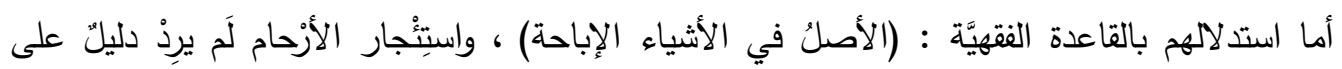

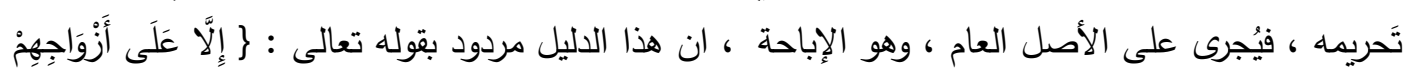

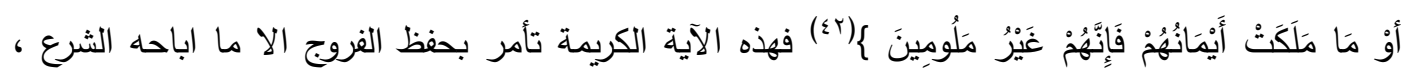

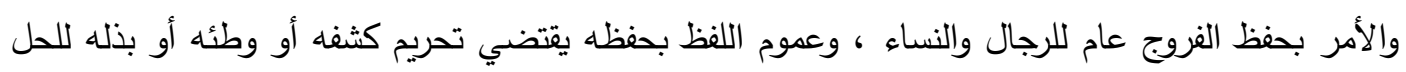

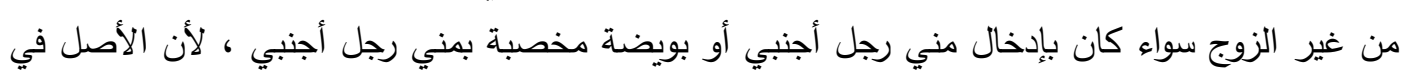

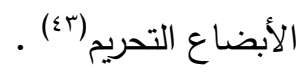

أما ما استدلوا به بقياس الرحم على الثذي بجامع التغذية في كلٍٍ منهما ، أو الاستئجار في كلٍ منهما

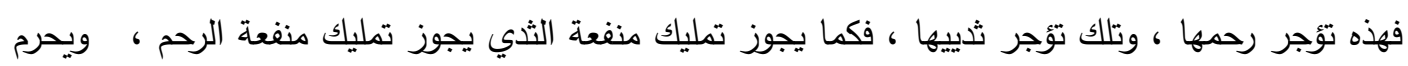

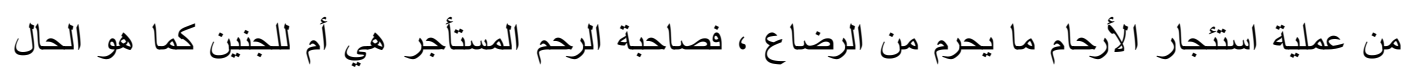


العـــــــد الثاني والثلاثون

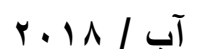

في أمه من الرضاعة ، وأن الله تعالى جمع بين الحمل والرضاع في المدة اللازمة لهما في قوله تعالى :

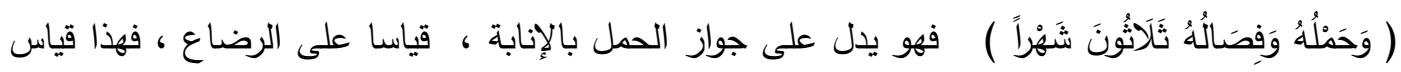

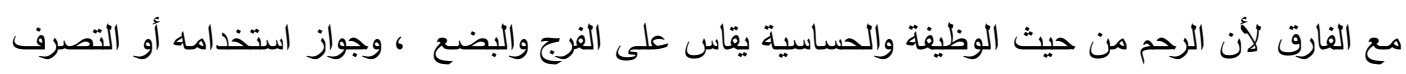

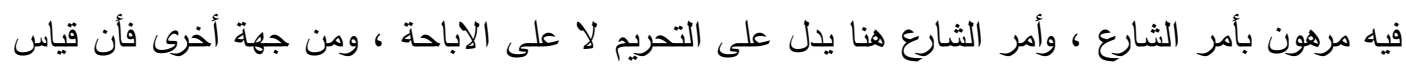

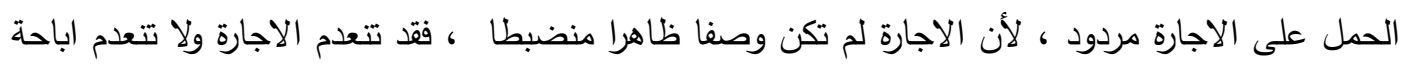

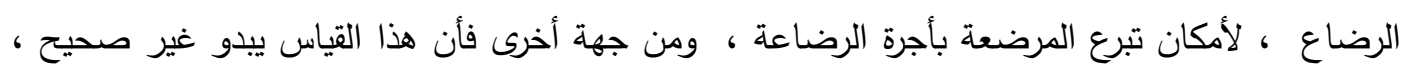

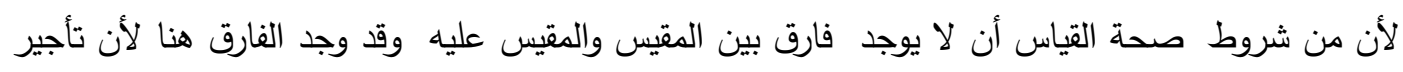

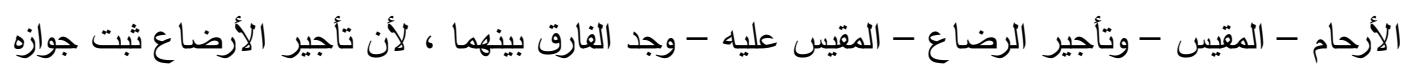

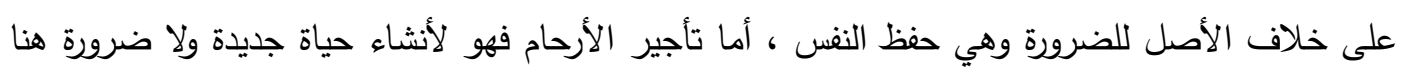

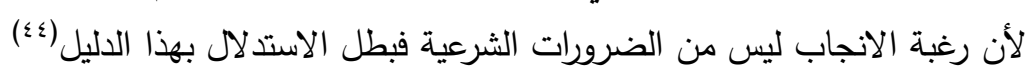

وعن قولهم بأن علماء الطب صرحوا انه حينما تتحد البويضة مع الحيوان المنوي الذكر يتم التزاوج بين

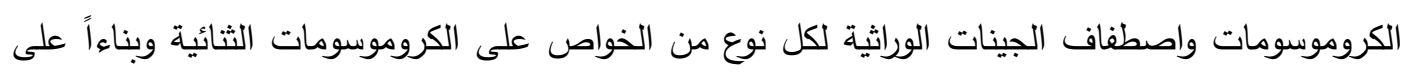

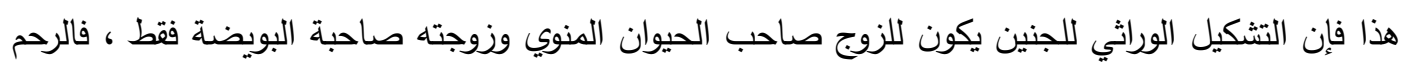

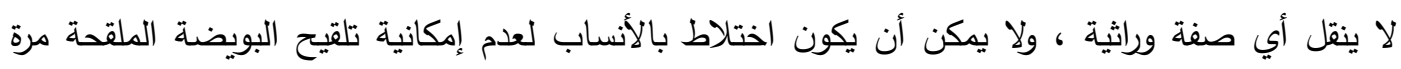

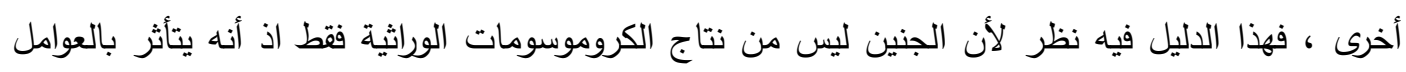

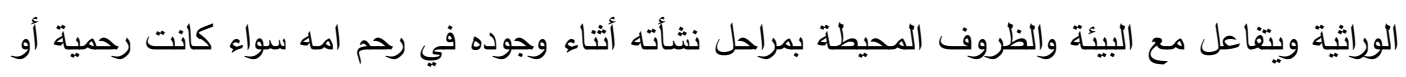
شرعية فالرحم البديل ليس مجرد وعاء لأنه يغذي الجنين ويؤثر فيه وراثيا ، وهذا ما أثبته فئه الدراسات

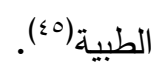

أما قولهم بأن صورة استئجار الأرحام فيها معنى الزوجية ، فهي ليس فيها وطء محرم ولا تعتبر زنا وليس

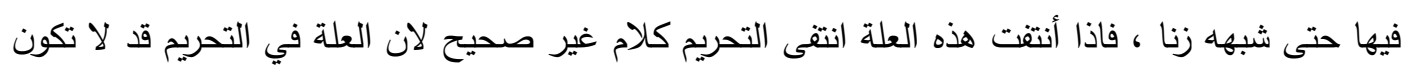

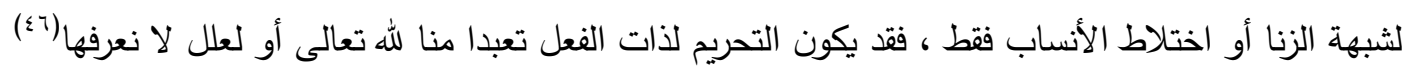


العــــــد الثاني والثلاثون

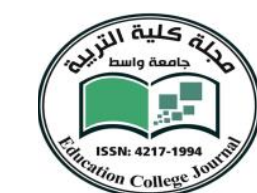

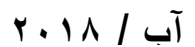

مجلـــة كليـــة التربيـــة

أما قولهم ان الآيات القرآنية الكريمة التي تتحدث عن المحرمات مثل قوله تعالى : \} حُرِّمَتْ عَلَيَكُمْ

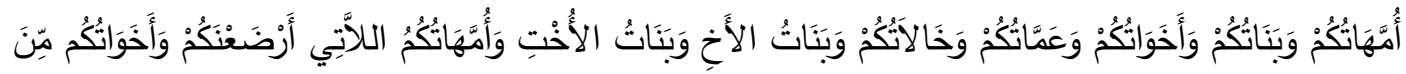

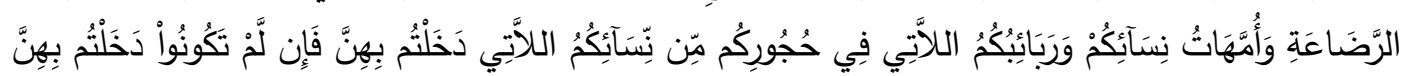

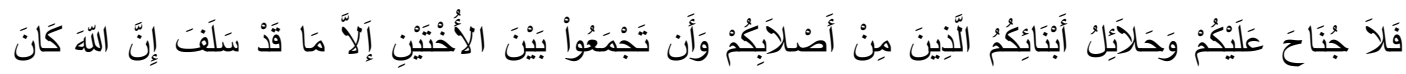

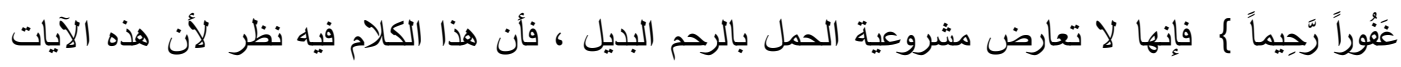

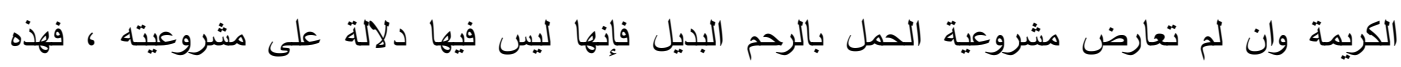

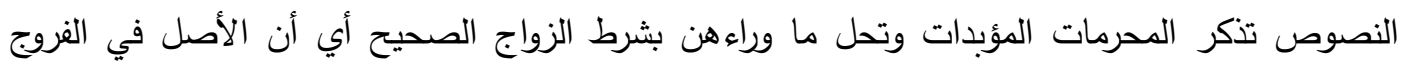

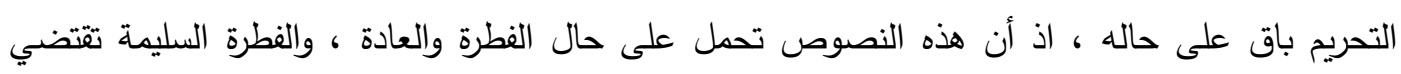

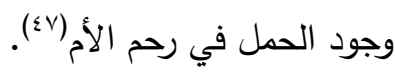




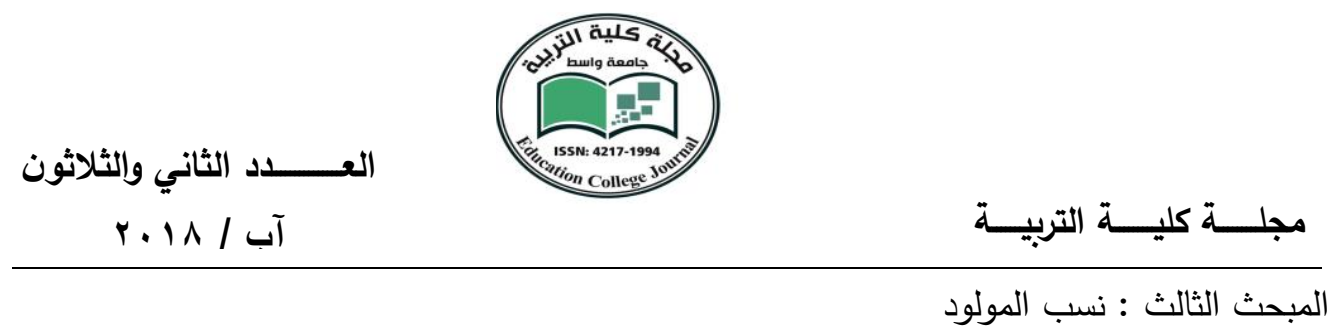

اختلف الفقهاء في نسب المولود من ناحية امه ، وكذلك اختلفوا في نسبه من ناحية الأب ، وتبعا لهذا

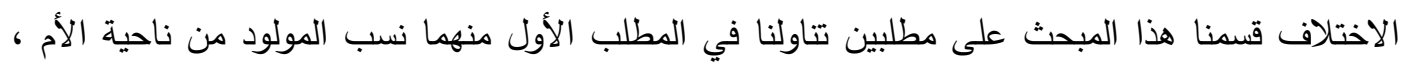
أما المطلب الثاني فتتاولنا فيه نسب المولود البحد من ناحية الأب وكما يأتي :

$$
\text { المطلب الأول : نسب المولود من ناحية الأم }
$$

اختلف الفقهاء في نسب المولود من ناحية الام في حال الحمل بالرحم البديل فذهب قسم منهم الى ان الأم

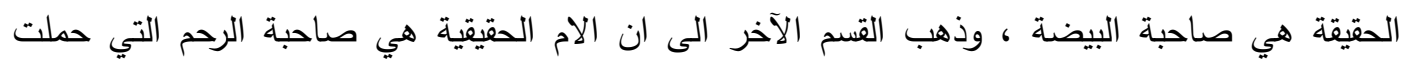

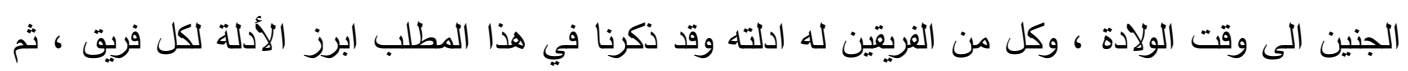

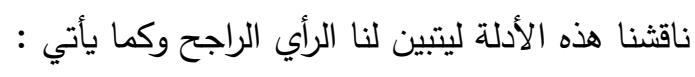

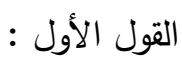

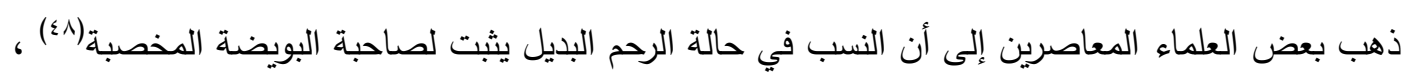
واستدلوا على ما ذهبوا اليه بأدلة منها :

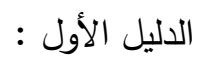

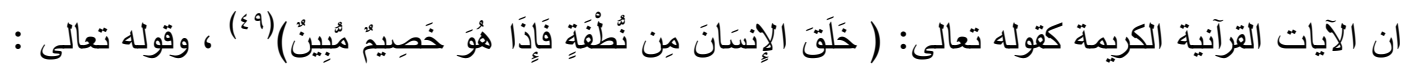

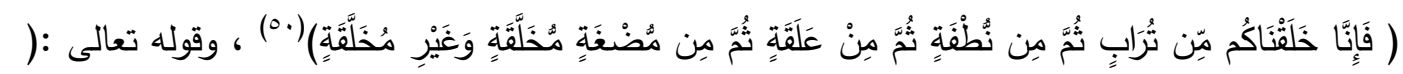

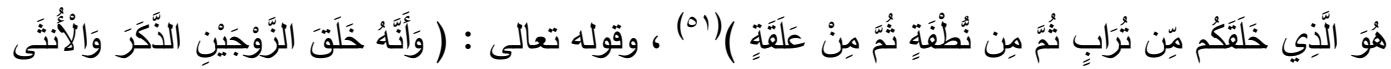

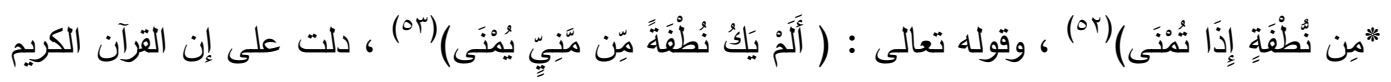

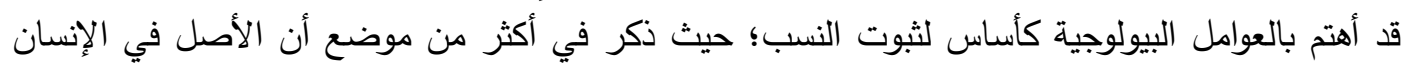

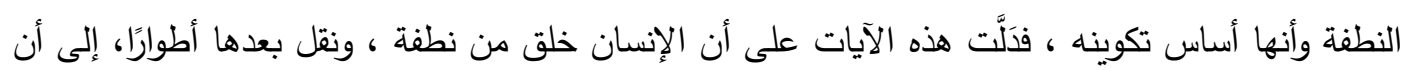




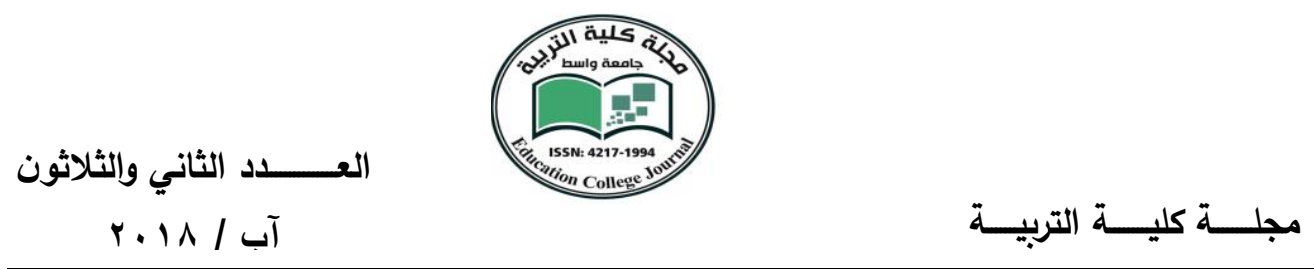

وُُلِد ونشأ ، مما يدل على أن الولد ينسب لصاحبة البويضة التي خُمِبِت بماء زوجها وفقًا للحقيقة البيولوجية

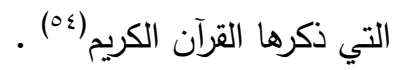

الدليل الثاني : القياس على الثمرة ؛ فإن الثمرة بنت البذرة لا بنت الأرض، فمن يزرع برتقالا يجني برتقالا

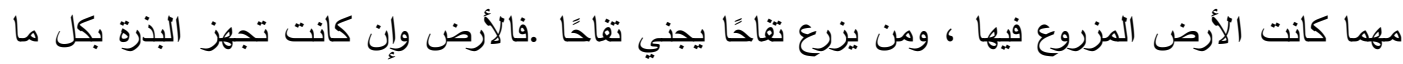

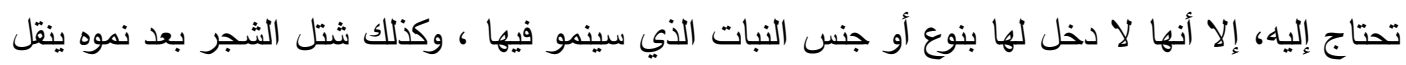

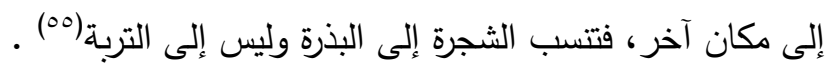

الدليل الثالث : ان المرأة المتبرعة بالحمل لا يستقيد منها الولد سوى الغذاء، فأشبه ما يكون بطفل تغذَّى من

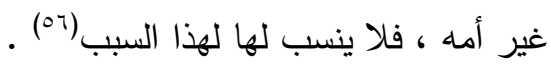

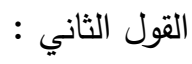
ذهب أصحاب هذا القول الى أن النسب في حالة الرحم البديل يثبت لصاحبة الرحم البديل لا إلى صاحبة

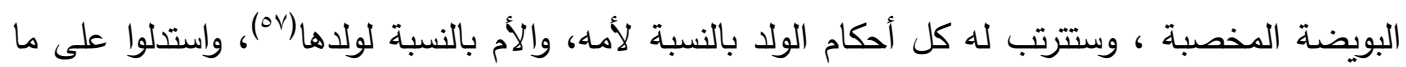
ذهبوا اليه بأدلة منها :

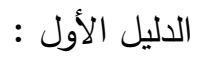

الآيات القرآنية الكريمة التي دلت بصريح النص على أن الأم هي التي تحمل وتلد ، وأن التي يتم التخليق

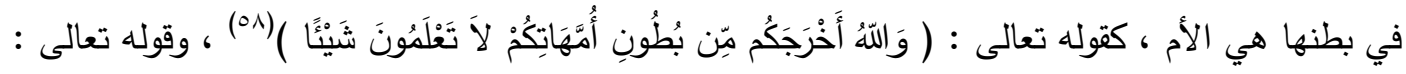

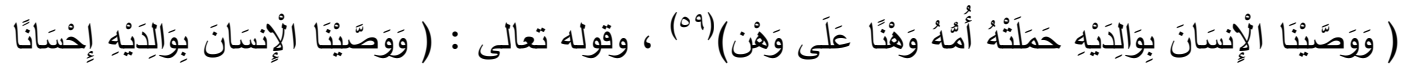

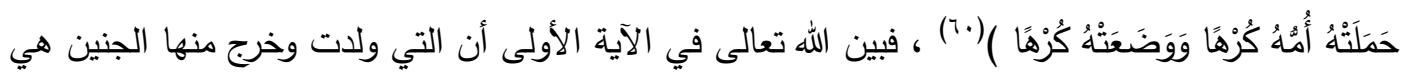

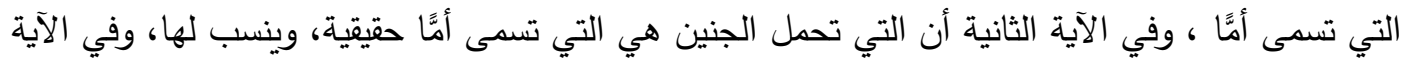

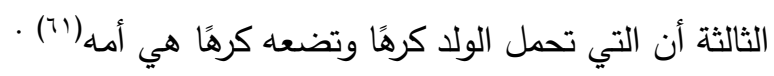




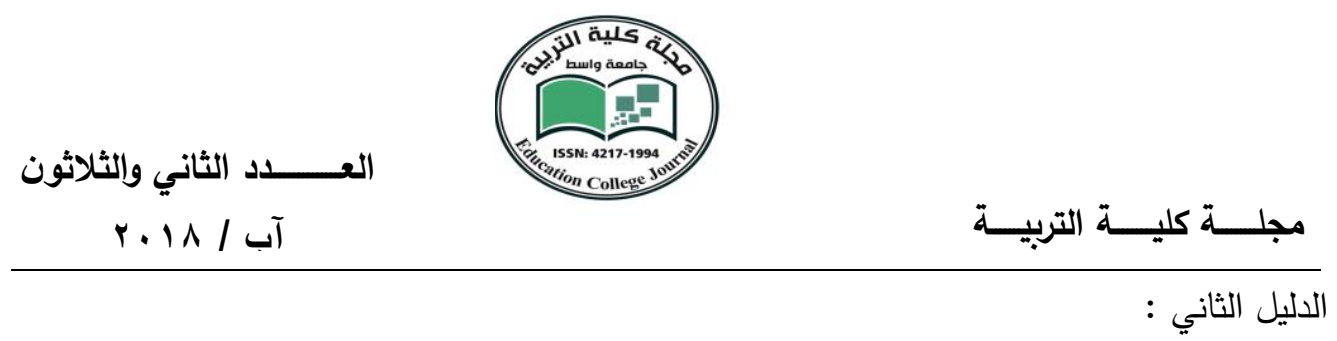

أثبت القرآن الكريم صفة الأمومة للتي حملت وولدت، بأسلوب يدل على اختصاصها بتلك الصفة ، كما

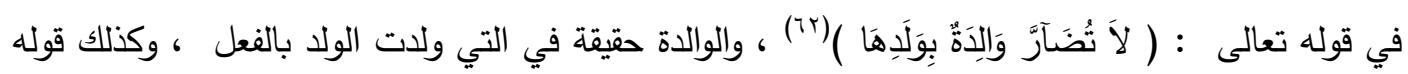

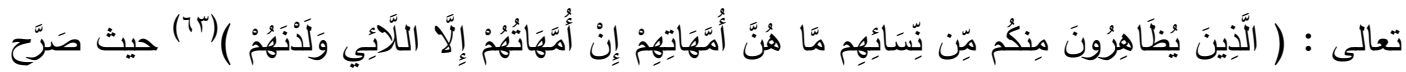

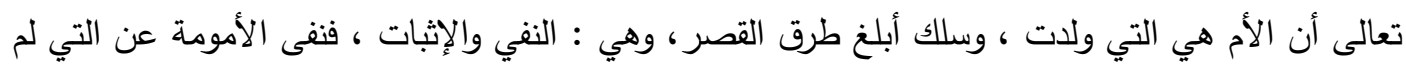
تلد الولد، وأثبتها للتي ولدات (؟َ). الاليل الثالث : n (n) قول رسول الله

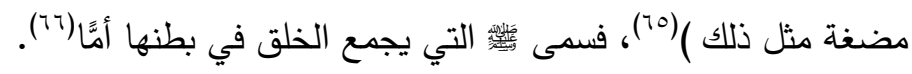

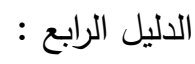
استدلوا بما رو بما روته أم المؤمنين عائشة - رضى الله عنها - انها قالت : اختصم سعد بن أبي وقاص وعبد بن زمعة في غلام ، فقال سعد: هذا يا رسول الله ابن أخي عتبة بن أبي وقاص عهد الي أنه ابنه ، انظر الى شبهه ، وقال عبد بن زمعة : هذا أخي يا رسول الله ولا على فراش أبي من وليدته ، فنظر رسول

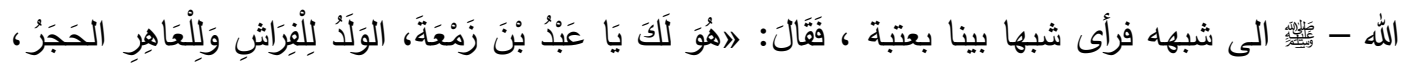

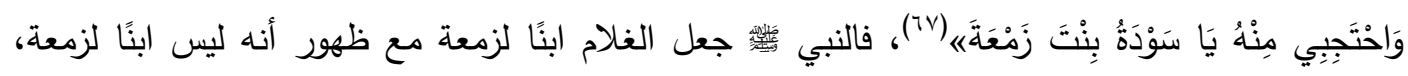

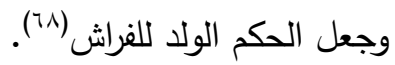




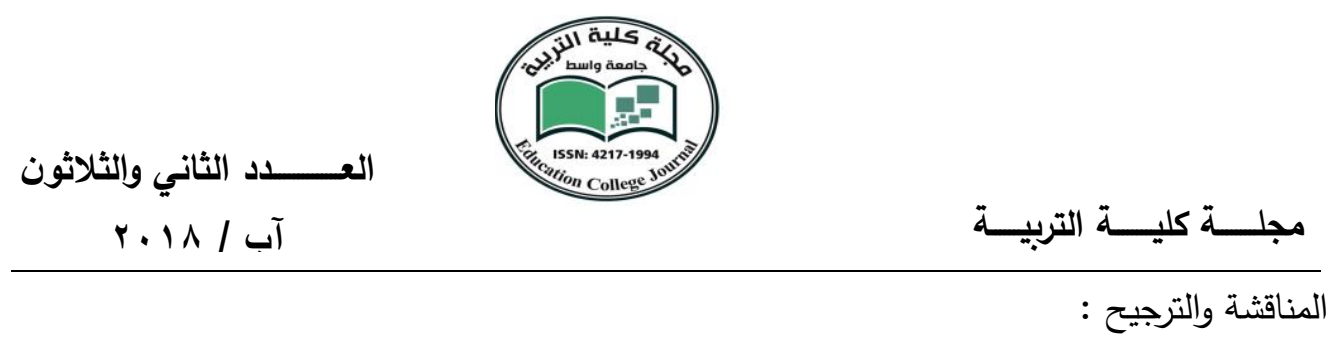

ان ما استدل به أصحاب القول الأول - النسب في حالة الرحم البديل يثبت لصاحبة البويضة المخصبة - بقولهم إن القرآن الكريم قد اهتم بالعوامل البيولوجية كأساس لثبوت النسب؛ حيث ذكر في أكثر من موضع

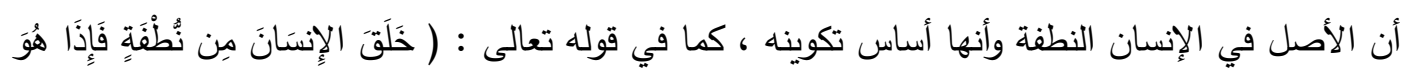

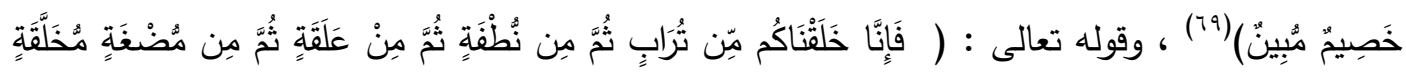

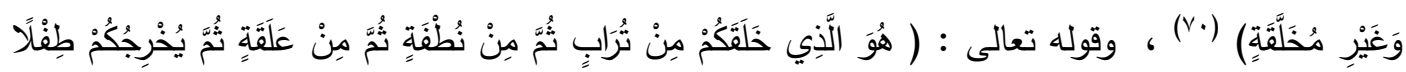

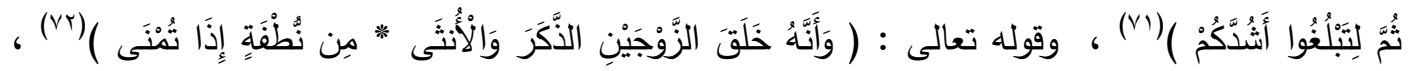

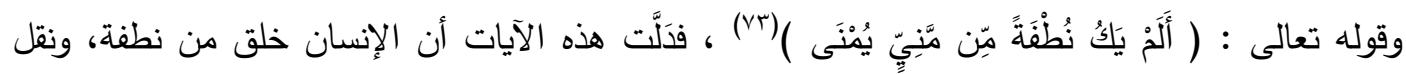
بعدها أطوارًا، إلى أن وُلِّد ونشأ، مما يدل على أن الولا ينسب لصاحبة البويضة التي خُصِّبت بماء زوجها وفقًا للحقيقة البيولوجية التي ذكرها القرآن الكريم ، فان هذا الدليل فيه نظر لأن الماءين إن لم يكونا محترمين حال الإدخال والإخراج أو فيهما، يصبحان هدرًا لا حرمة لهما مطلقًا؛ فالعوامل البيولوجية معتبرة إن كانت في الإطار الذي رسمه الثارع ، وهذا الإطار مضبوط في ثبوت النسب بأسبابه :كالفراش والبينة ، والأم البديلة ليست بفراش لزوج صاحبة البويضة المخصبة ، والمدار كله على اعتبار الثرع ، فالزاني وإن كان

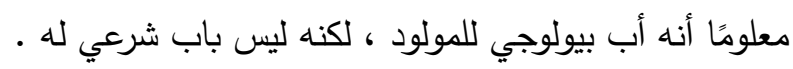

أما قولهم إن المرأة المتبرعة بالحمل لا يستقيد منها الولد غير الغذاء، فأشبه ما يكون بطفل تغذَّى من غير أمه ، فلا ينسب لها لهذا السبب ، فقد نوقش هذا الاليل بمنع أن يكون الولد لا يستفيد من المرأة المتبرعة بالحمل غير الغذاء ، فقد ثبت أن الرحم يؤثر في الصفات الوراثية للجنين ، وليس مجرد عامل مساعد كما

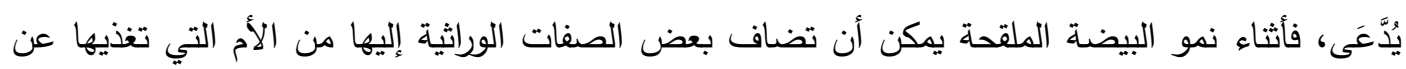

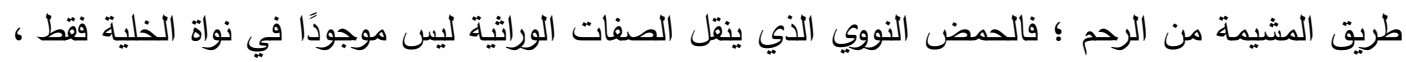
وإنما في سيتوبلازم الخلية، وهذا الجزء من الحمض يتأثر بالبيئة المحيطة به أثناء نمو الجنين في الرحم ،

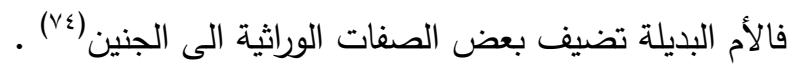




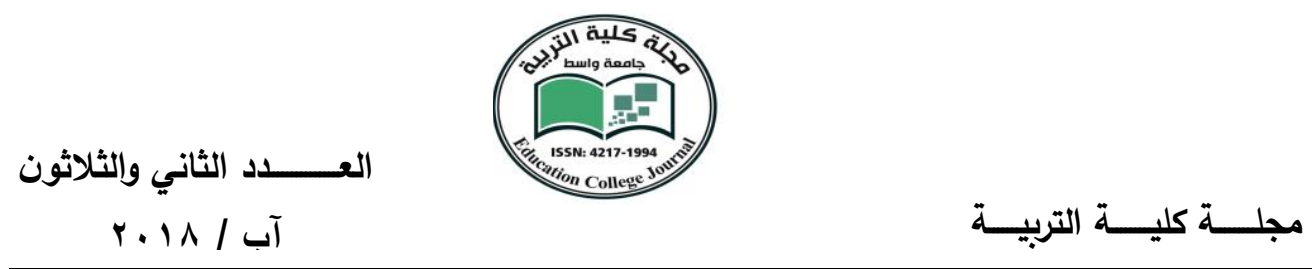

أما استدلالهم بالقياس على الثمرة ؛ فإن الثمرة بنت البذرة لا بنت الأرض ، فمن يزرع برتقالا يجني برتقالا

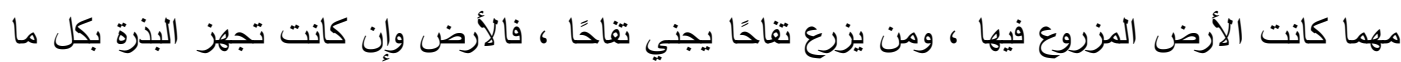
تحتاج إليه ، إلا أنها لا دخل لها بنوع أو جنس النبات الذي سينمو فيها ، وكذلك شتل الشجر بعد نموه وكبره ، فينقل إلى مكان آخر، فتتسب الثجرة إلى البذرة وليس إلى التربة ، فهو دليل مردود لأنه قياس مع قيام الفارق ، وأن هذا القياس هو من القياس الصوري ، والقياس الصوري أضعف أنواع قياس الشبه عند

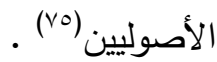

اما الأدلة التي استدل بها أصحاب الفريق الثاني - القائلون أن النسب في حالة الرحم البديل يثبت لصاحبة الرحم البديل لا إلى صاحبة البويضة المخصبة ، فما استدلوا به بقولهم ان الآيات القرآنية الكريمة التي دلت بصريح النص على أن الأم هي التي تحمل وتلد، وأن التي يتم التخليق في بطنها هي الأم، كقوله تعالى :

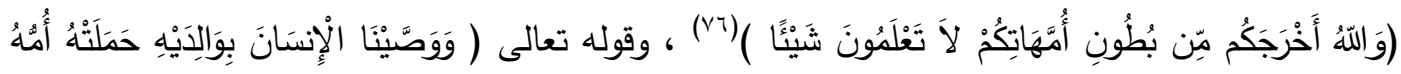

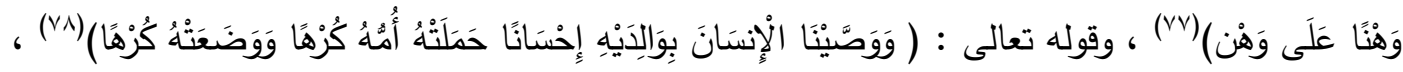
فبين الله تعالى في الآية الأولى أن التي ولدت وخرج منها الجنين هي التي تسمى أهَّا، وفي الآية الثانية أن التي تحمل الجنين هي التي تسمى أمَّا حقيقية، وينسب لها .وفي الآية الثالثة أن التي تحمل الولد كرهًا وتضعه كرهًا هي أمه ، ونوقش هذا الاستدلال بأن الأم الحقيقية على مر التاريخ ووقت نزول القرآن هي مجموعة الهيئة التي هي صاحبة الحمل والوضع وهي ذاتها وفي الوقت نفسه صاحبة البويضة فكل مولود له بأمه صلتان :صلة تكوين ووراثة ، وأصلها البويضة وصلة حمل وولادة وحضانة ، وأصلها الرحم فإطلاق الأم على التي حملت ووضعت فقط من غير أن تكون البويضة منها ، إطلاق على غير الهيئة الكاملة لها

وقت التنزيل (va)

اما قولهم بان القرآن الكريم أثبت صفة الأمومة للتي حملت وولدت ، بأسلوب يدل على اختصاصها بها ،

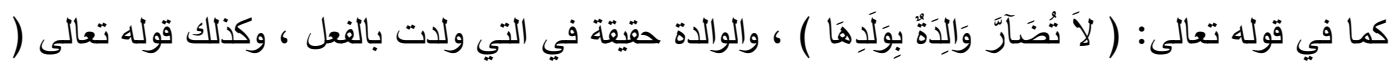

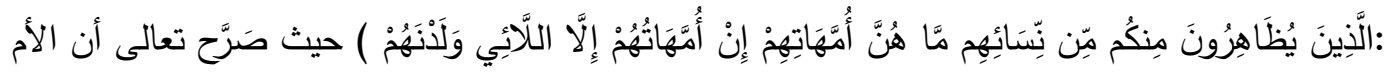
هي التي ولدت ، وسلك أبلغ طرق القصر ، وهي : النفي والإثبات ، فنفى الأمومة عن التي لم تلد الولد ، وأثبتها للتي ولدت فالاستدلال بآية الظهار بعيد، وذلك أن المقصود الرد على الذين يظاهرون من نسائهم 
العـــــــد الثاني والثلاثون

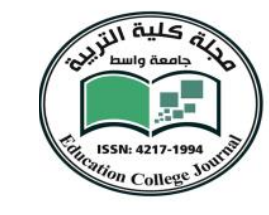

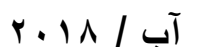

مجلـــة كليـــة التربيــة

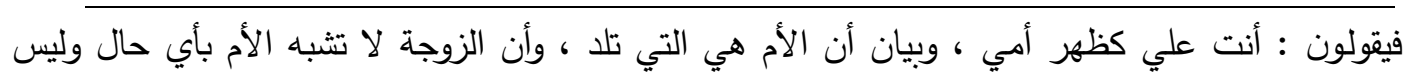

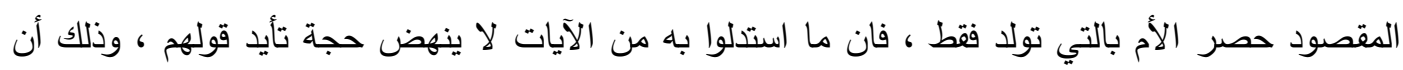

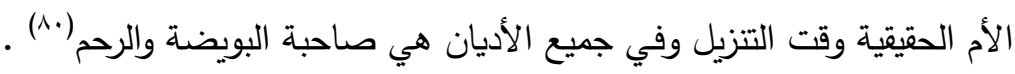

اما استدلالهم بقول رسول الله

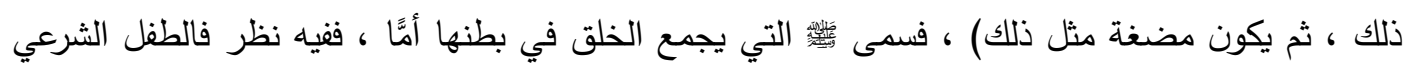

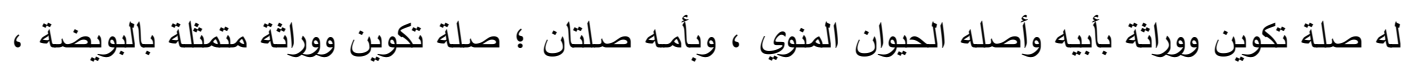

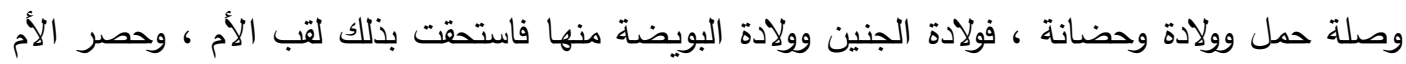

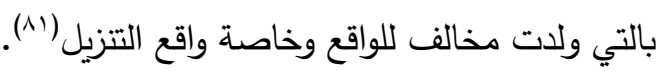

اما استدلالهم بما روته أم المؤمنين عائشة رضي الله عنها أن سعد بن أبي وقاص وعبد بن زمعة اختصما

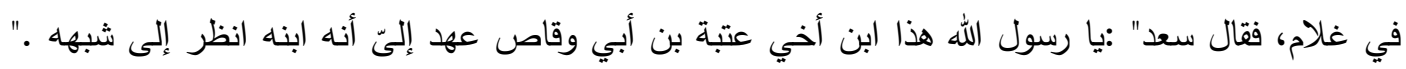

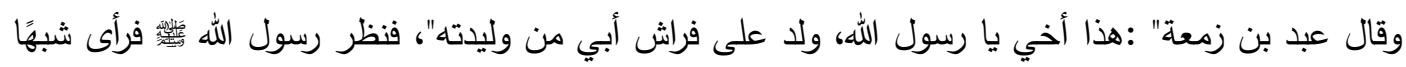

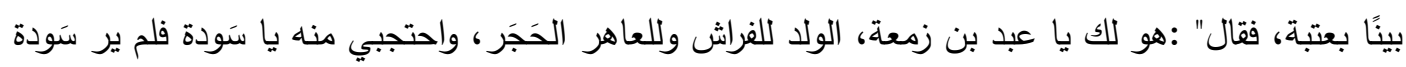

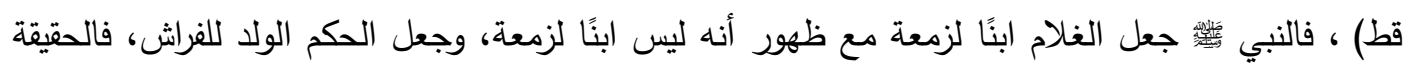

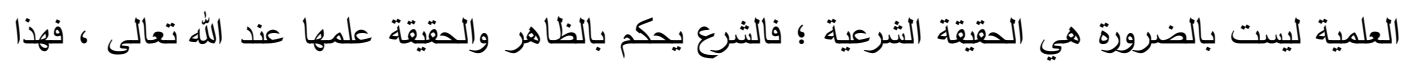
الدليل فيه نظر لأن الصورة التي معنا مختلفة عن قصة زمعة ، ففي قصة زمعة محتمل ان يكون الجنين

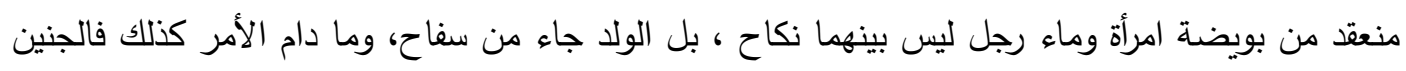

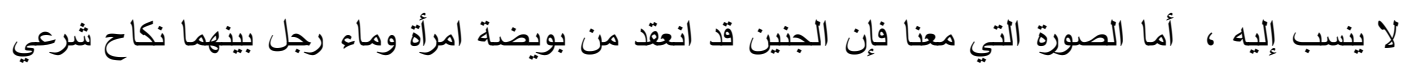

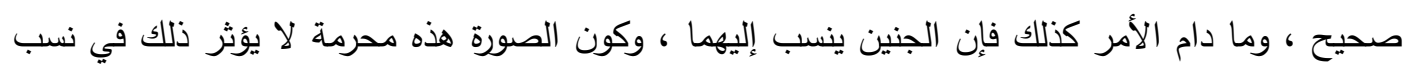

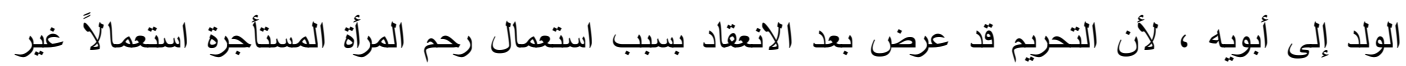

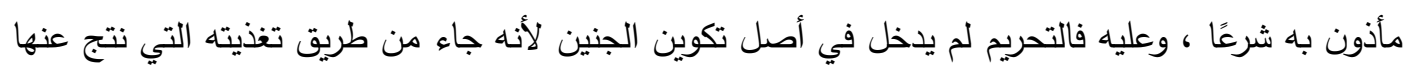

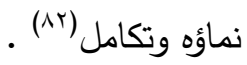


العــــــــد الثاني والثلاثون

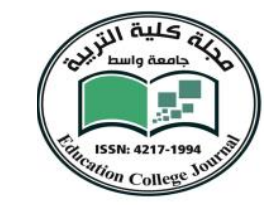

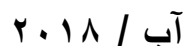

مجلــــة كليــــة التربيـــة

والذي أرجحه والله اعلم أن الأم الحقيقة هي التي تبرعت بالبويضة لان الجنين أصلا هو التحام خلية الزوج

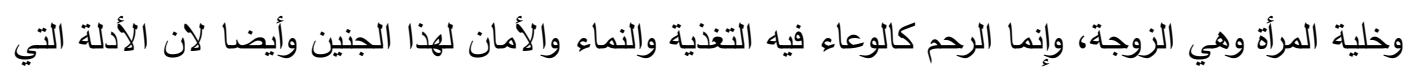
أوردها علماء الفريق الثاني وهي الآيات الكريمة تتحدث عن الأم الحقيقة التي حملت والتي ولدت أيضا، فهي تتتاول تلك الأم التي أعطت البويضة والتي أعطت الرحم، أما الأم المستعارة فهي لم تعط البويضة والتي هي التي الأساس فقط أعطت الرحم، لذلك لا يمكن أن تشير الآيات أعلاه إلى هذا النوع من الأمهات، فمعاني هذه الآيات لا تفسر هذه المسألة الطبية العصرية فالنصوص أعلاه لا تتحملها ، لذلك يثبت للأم صاحبة البويضة جميع أحكام الميراث والنفقة والحضانة وغيرها.

المطلب الثاني : نسب المولود من ناحية الأب :

انقسم الباحثون في هذه المسألة على قولين (r^) هما :

القول الأول : n

ذهب بعض العلماء إلى أن المولود ينسب إلى أبيه - زوج صاحبة البويضة - الذي لقحت بويضتها بمائه ،

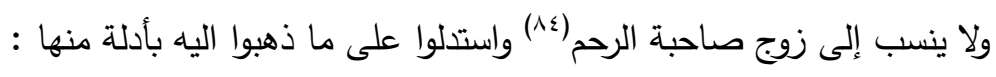

1 - ان هذه الصورة مبنية على أساس أن اللقيحة جاءت من بويضة امرأة لقحت بماء زوجها ، ثم بعد التلقيح زرعت في رحم امرأة أخرى ، فالجنين قد انعقد من بويضة امرأة وماء رجل بينهما نكاح شرعي صحيح ، وما دام الأمر كذلك فالجنين ينسب إليهما ، وكون هذه الصورة محرمة لا يؤثر ذلك في نسبة الولد إلى أبويه ، فالتحريم لم يدخل في أصل تكوين الجنين، وإنما جاء من طريق تغذيته التي نتج عنها نماؤه وتكامله

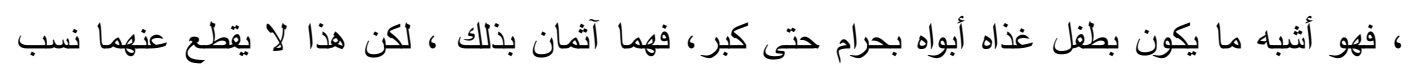
ابنهما (10)

ب - ان كثيرا من العلماء يقولون بلحوق ولا الزنا بمن يدعيه اذا كانت الزانية غير متزوجة ، أي لم يكن مولودًا على فراش يدعيه صاحبه ، فيمكن ان نقول تخريجًا على هذا الحكم بلحوق الطفل الذي ولد بطريقة 


\section{العــــــد الثاني والثلاثون}

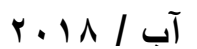

مجلـــة كليـــة التربيــة

تأجير الأرحام ، بصاحب الحيوان المنوي ، الذي لقحت به البييضة التى وضعت في رحم امرأة ليست

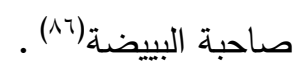

r - - ان النسب يشترط فيه المشروعية أثناء إنزال المني ، ولا يشترط فيه الشروعية أثناء الإدخال في ،

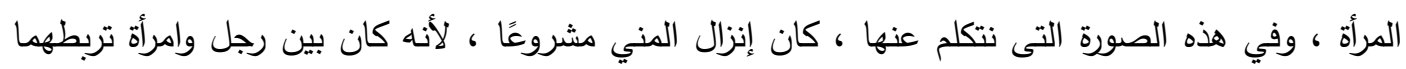

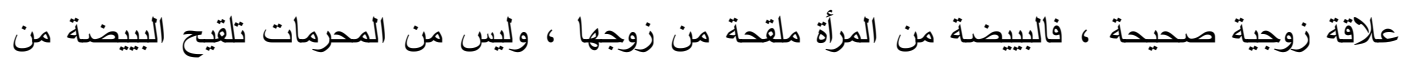

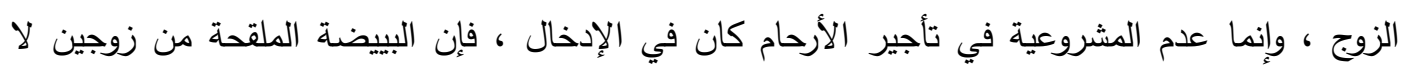

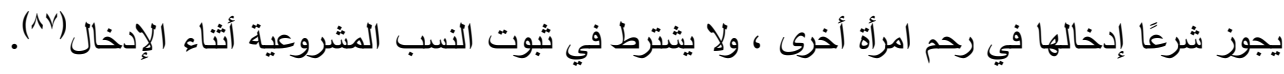
ع - ان الاكتشافات العلمية الحديثة أثبتت أن أنسجة الجسم مكونة من خلايا ، وكل خلية تحتضن نواة هي

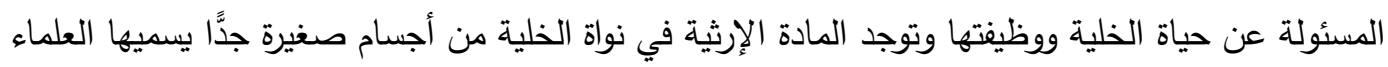

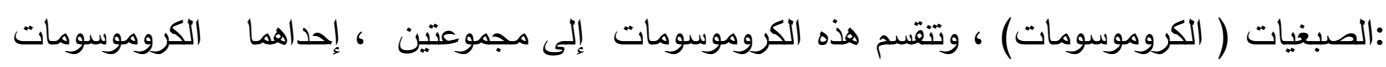

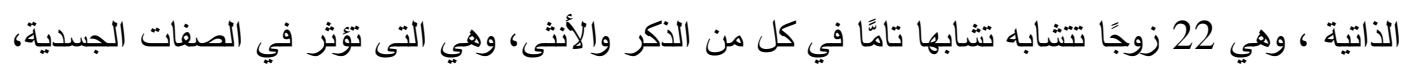
كطول القامة ، ولون الشعر ، ولون العين ، ولون البشرة ، والقابلية للأمراض.

وثانيهما هي الكروموسومات الجنسية ، وعددها زوج واحد ، وهو متماثل في الأنثي يسمى كرموسوم X بينما

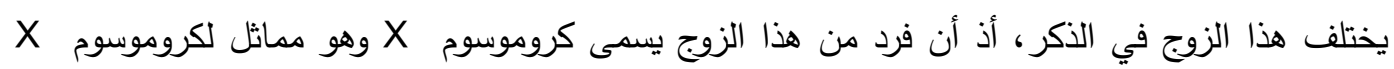

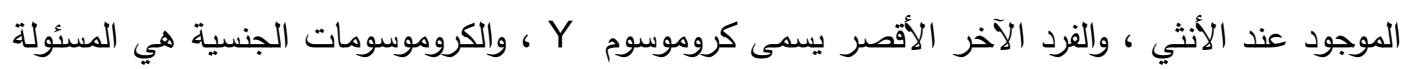

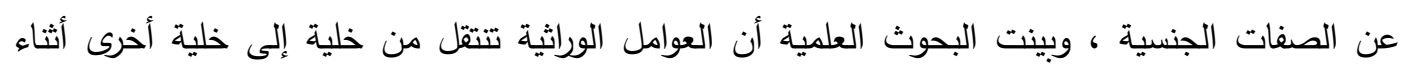

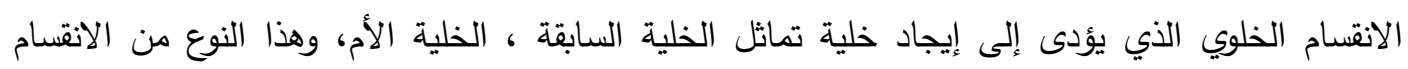

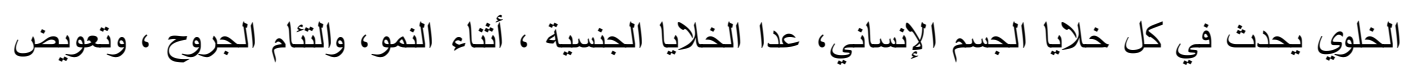

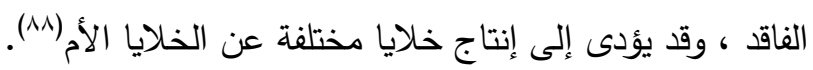

ومما سبق يتبين أن انتقال البييضة من المرأة الملقحة بالحيوان المنوي من زوجها، إلى رحم امرأة أخرى

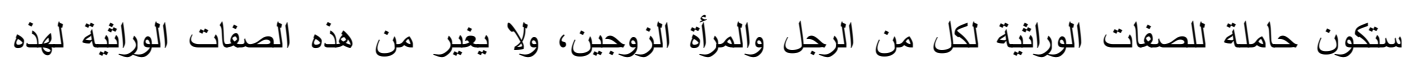

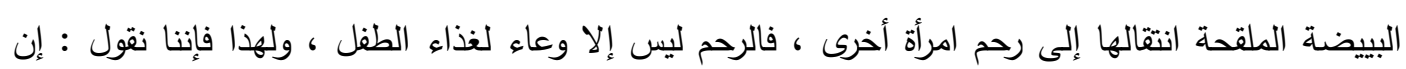


العــــــــد الثاني والثلاثون

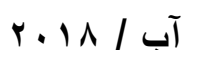

مجلـــة كليـــــة التربيـــة

الطفل الذي سيكون نتيجة تأجير الرحم ، هو ابن للزوجين اللذين أخذت منهما البييضة الملقحة ، وليست المرأة صاحبة الرحم المنقول إليها البييضة المخصبة أمَّا للطفل من النسب ، وإنما هي أمه من الرضاع ، تسرى عليها كل الأحكام التى تسرى على الأم من الرضاع، من تحريم الزواج، وجواز النظر الذي يجوز للمحارم والخلوة وغير ذلك.

القول الثاني : n

ذهب أصحاب هذا الفريق إلى أن نسب المولود من ناحية الأب هو لزوج صاحبة الرحم على الرغم من عدم

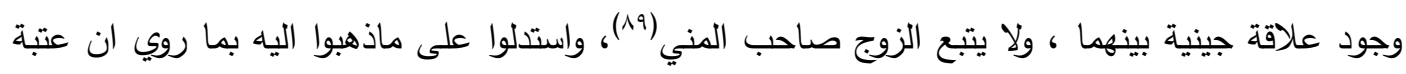
عهد الى أخيه سعد : ان ابن وليدة زمعة مني فاقبضه اليك ، فلما كان عام الفتح أخذه سعد فقال : ابن أخي عهد الي فيه فقال عبد بن زمعة : أخي وابن وليدة أبي ، ولد على فراشه ، فقال النبي : هو لك يا عبد بن زمعة ، الولا للفراش وللعاهر الحَجَر، ثم قال لسودة بنت زمعة احتجبي منه لما رأى من شبهه بعتبة ، فما

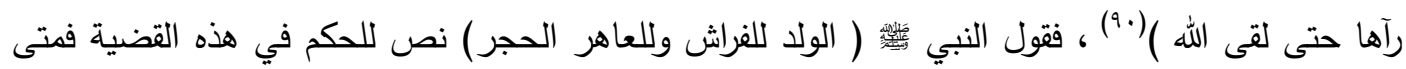
حملت أم بديلة ذات زوج نتيجة زرع لقيحة زوج في رحمها ، فان الحمل ينسب لزوج الزوجة التي حملت به

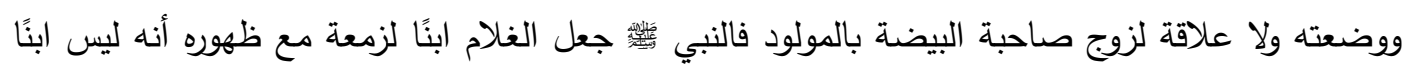
لزمعة ، وجعل الحكم الولد للفراش فالحقيقة العلمية ليست بالضرورة هي الحقيقة الثرعية ؛ فالثرع يحكم بالظاهر والحقيقة علمها عند الله تعالى عملا بقاعدة صحة دعوى العموم فيما جاء عن الشارع ابتداء((9).

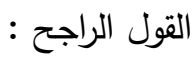

إذا حصل القطع واليقين في مصدر الجنين، بأن الولد ليس لزوج صاحبة الرحم ، فإن المولود لا يلحق به، لأنه ليس منه ، لأن سبب ثبوت النسب من الزوج كونه مخلوقًا من مائه ، كمن تزوج فولدات امرأته لأقل من لأن ستة أشهر، أو إذا ولدت زوجة الصغير، فالولا لا ينسب للزوج إجماعًا، ولو نسب إليه المولود بحسب كابل الظاهر، وهو يعلم يقينًا أنه ليس منه ، وجب عليه نفي الولد ، لأن استلحاق من ليس منه حرام وعليه

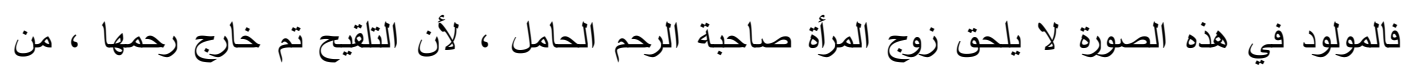
بويضة ليست لها ، ومن مني ليس لزوجها، فالحمل ليس من مائه قطعًا ولا علاقة جينية بينهما، فلا يجوز 


\section{العــــــد الثاني والثلاثون}

آب /

نسبة المولود إليه قطعًا، ولو نسب إليه بحسب الظاهر وجب نفيه ـ أما نص الحديث ( الولد للفراش وللعاهر

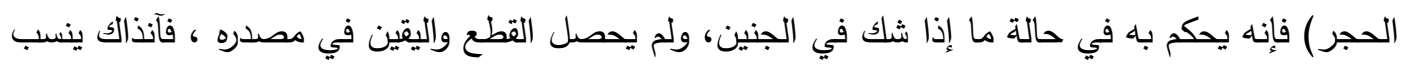

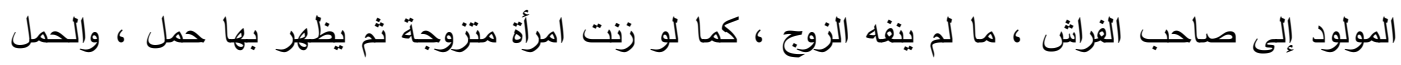

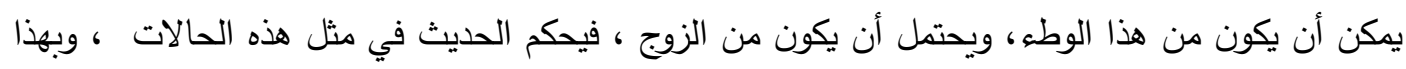

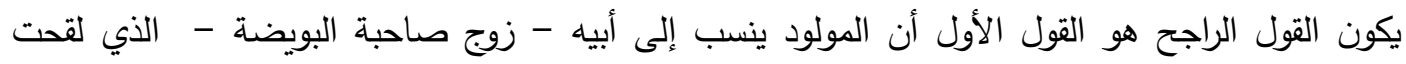

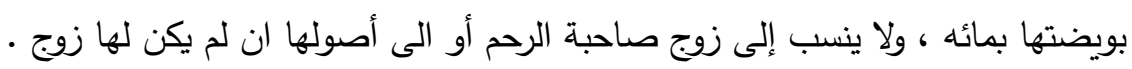

\section{الخاتمة والنتائج}

ان الحمل البديل هو تلقيح بيضة أمرأة بحيمن رجل تلقيحا خارجيا في وعاء اختبار ثم زرع هذه التهاء البويضة الملقحة في رحم أي امرأه أخرى تقوم بحمله حتى ولادة الجنين سواء أكان الحمل بإرادتها أم بالإكراه

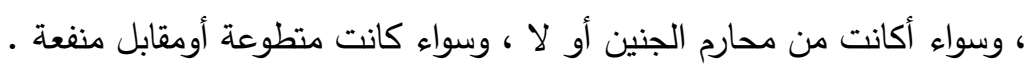

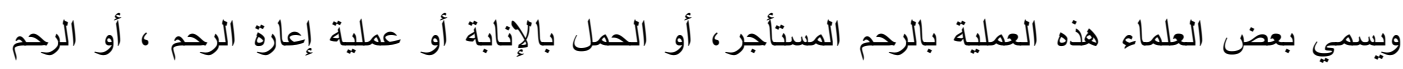

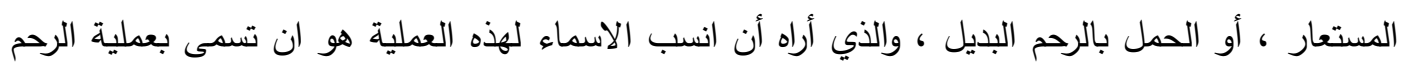

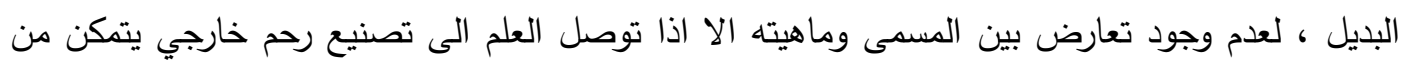

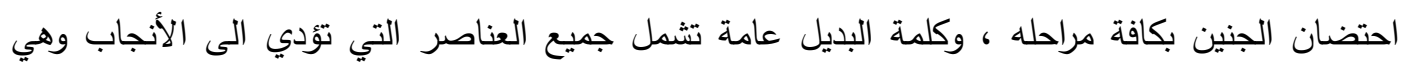
الحيمن والبيضة والرحم .

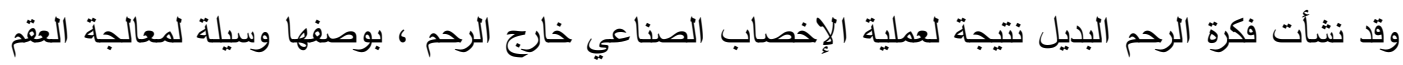
لاى غير القادرين على الإنجاب بالطرق الاعتيادية .

وقد تعددت صور الرحم البديل يمكن بيانها في ثمانية صور ولكل صورة من هذه الصور حكما خاصا بها

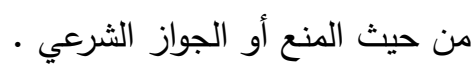

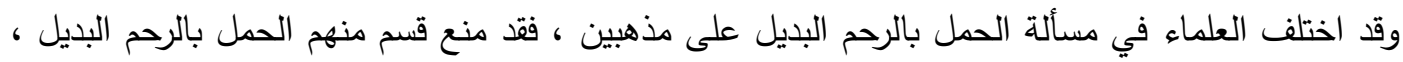
وقد أجازه القسم الآخر ، والقول الأول هو الراجح . 


\section{العـــــــدد الثاني والثلاثون}

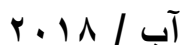

وقد اختلف الفقهاء في نسب المولود من ناحية الام في حال الحمل بالرحم البديل فذهب قسم منهم الى ان الام الحقيقة هي صاحبة البيضة ، وذهب القسم الآخر الى ان الام الحقيقية هي صاحبة الرحم ، والقول

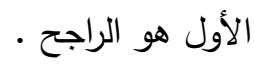

كما اختلف الفقهاء في نسب المولود من ناحية الأب فذهب بعض العلماء إلى أن المولود ينسب إلى أبيه زوج صاحبة البويضة - الذي لقحت بويضتها بمائه ، ولا ينسب إلى زوج صاحبة الرحم ، وذهب الفريق الثاني إلى أن نسب المولود من ناحية الأب هو لزوج صاحبة الرحم على الرغم من عدم وجود علاقة جينية

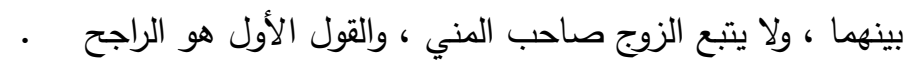

\section{ألهوامش والتعليقات}

$$
\begin{aligned}
& \text { (|) سورة النور ، الآية ب| - ع| . } \\
& \text { تفسير المراغي } 11 \text { / } 9 \text { ـ . }
\end{aligned}
$$

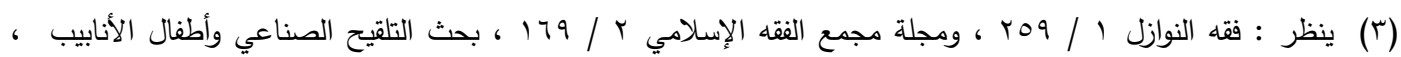

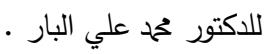

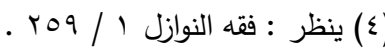

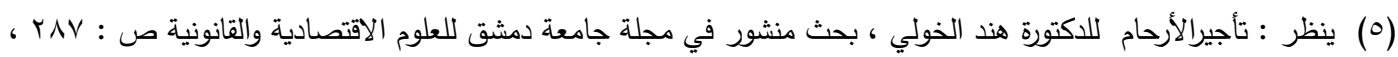

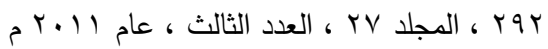

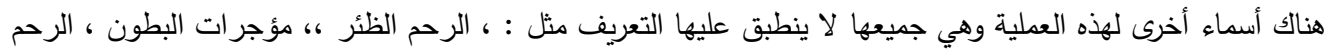

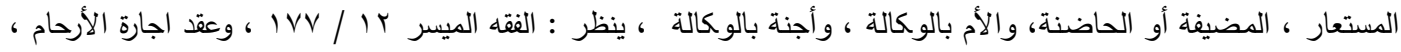

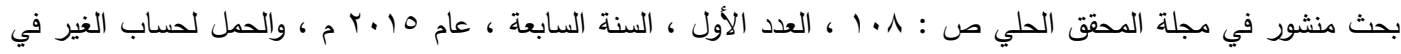

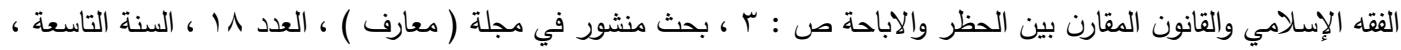

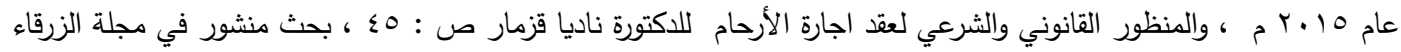

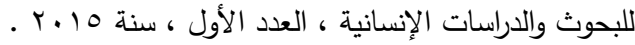




\section{العـــــــد الثاني والثلاثون}

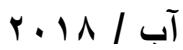

\section{مجلـــة كليـــة التربيـــة}

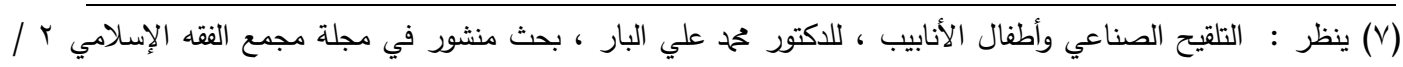

(9) ينظر : عقد اجارة الأرحام ، بحث منشور في مجلة المحقق الحلي ص : 9 (1 ، العدد الأول ، السنة السابعة ، عام 10 ب

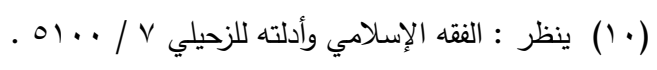

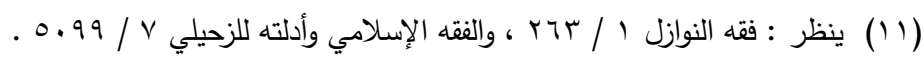

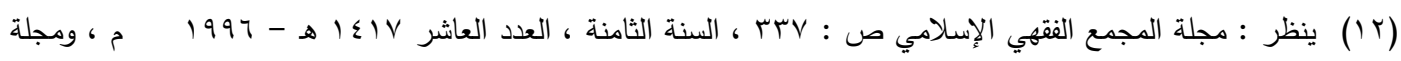

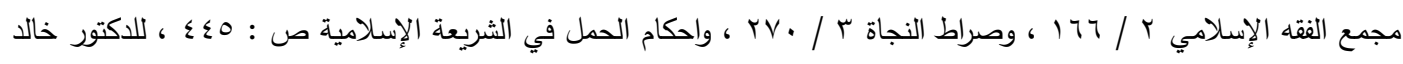

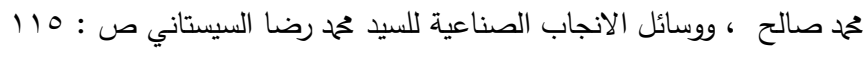

$$
\text { V- مورة المؤمنون ، الآية }
$$

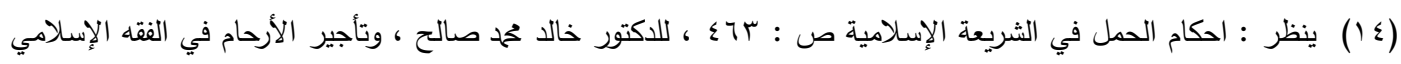

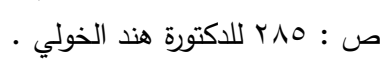

$$
\text { (10) ينظر : الأخصاب خارج الجسم ص : باجب للدكتور ماهر حامد الحولي }
$$

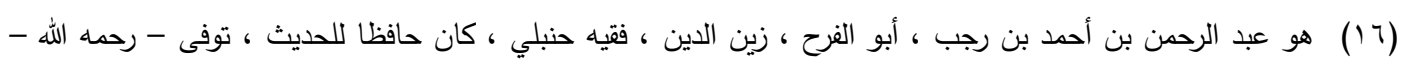

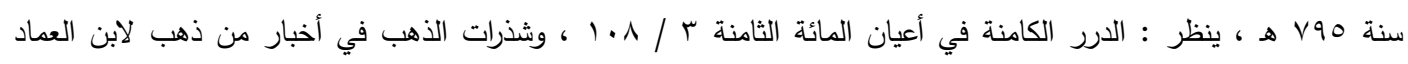

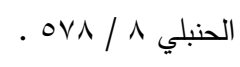

79 : القواعد لابن رجب ص ( V)

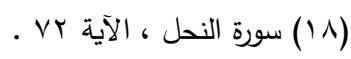

(9 (1) ينظر : الحمل لحساب الغير ص : 7 ، للدكتور الصادق ضريفي • 


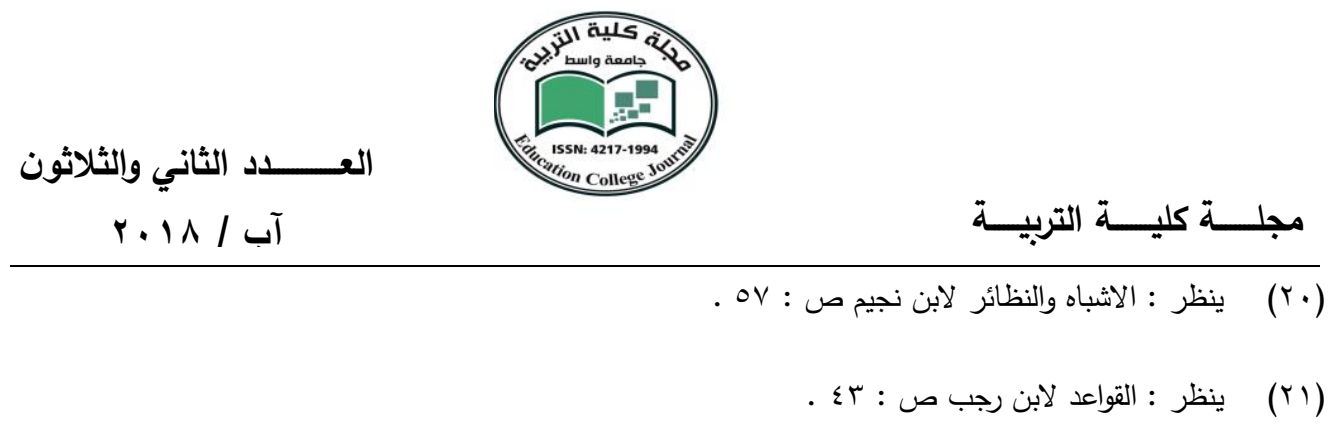

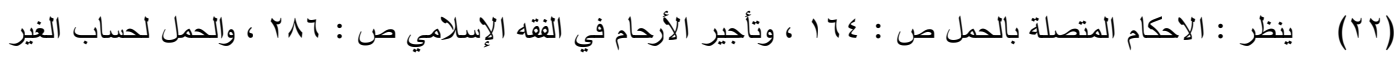

هو رويفع بن ثابت بن السكن النجاري ، صحابي جليل ، كان أميرا على طرابلس ، توفى - رضى الله عنه - سنة

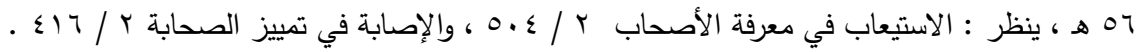

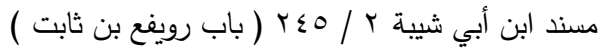

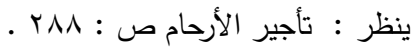

$$
\begin{aligned}
& \text { الأشباه والنظائر اللسبكي / / }
\end{aligned}
$$

ينظر : الاحكام المتصلة بالحمل ص : ؟ 1 ، وأحكام الحمل في الثريعة الإسلامية ص : ع ؟؟ .

$$
\text { ينظر : احكام الحمل في الشريعة الإسلامية ص : }
$$

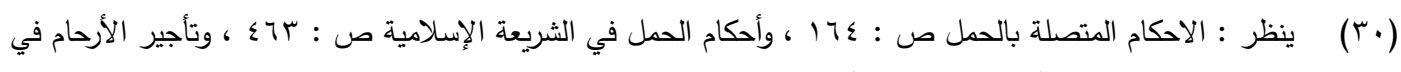

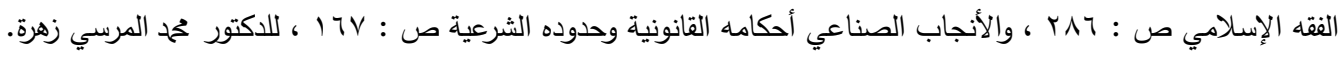

$$
\text { ينظر : الحمل لحساب الغير ص : ؟ }
$$

ينطر : الأحكام المتصلة بالحمل في الفقه الأسلامي ص : loV

$$
\text { الأشباه والنظائر لابن نجيم ص : M } 1 \text { الأشباه والنظائر للسيوطي ص : . }
$$




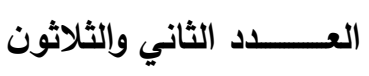

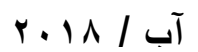

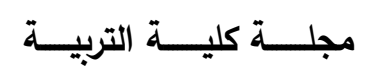

ينظر : الأشباه والنظائر للسيوطي ص :

سورة الأحقاف ، الآية 10 ـ ـ

ينظر : الأحكام المتصلة بالحمل في الفقه الأسلامي ص : 107

ينظر : أحكام الحمل في الشريعة الإسلامية ص: 10 .

ينظر : الأحكام المتصلة بالحمل في الفقه الأسلامي ص : 101

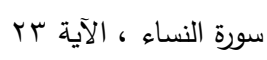

ينظر : أحكام الحمل في الثريعة الإسلامية ص : 99؟

ينظر : الحمل لحساب الغير ص : 11 .

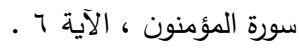

ينظر : الاحكام المتصلة بالحمل ص : . 17 ، والحمل لحساب الغير ص : 19 .

ينظر : الاحكام المتصلة بالحمل ص : 101، واجارة أرحام النساء في الفقه الإسلامي والفقه الوضعي ص : 9 ب1 .

ينظر : الاخصاب خارج الجسم ص : 11 ا .

ينظر : الاحكام المتصلة بالحمل ص : 101 ، والحمل لحساب الغير ص : 11 .

$$
\text { ينظر : أحكام الحمل في الشريعة الإسلامية ص : (V) . }
$$

ذهب الى هذا القول عدد كبير من العلماء منهم الثبراملسي من علماء الثافعية ، واليه ذهب الدكتور نعيم ياسين ،

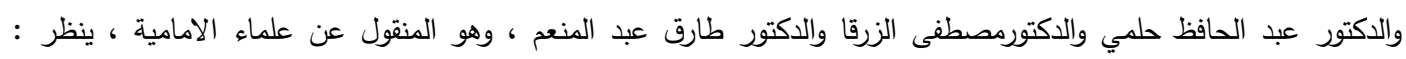

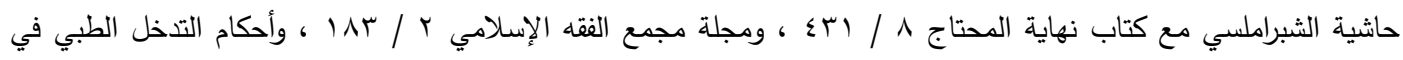

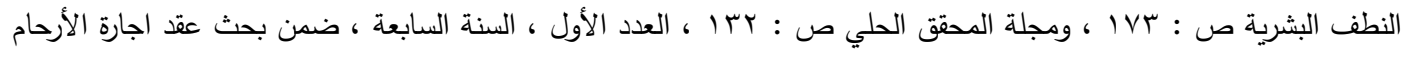




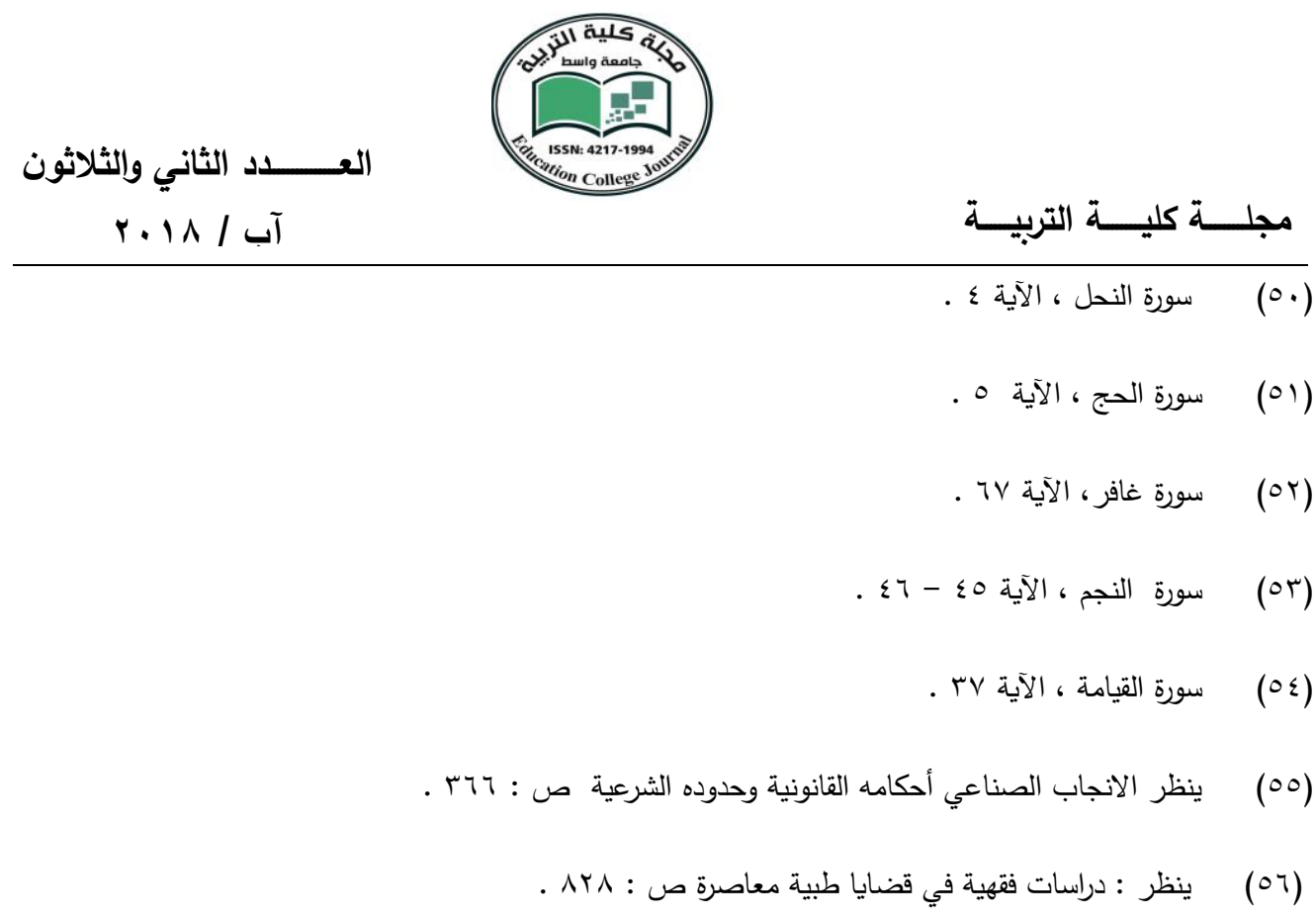

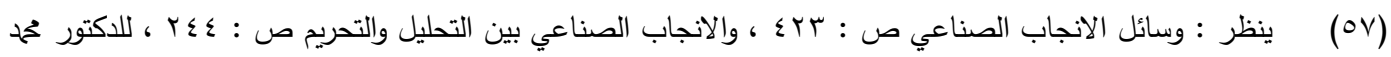
يحيى حسن النجمي .

(01) ذهب الى هذا القول عدد من العلماء منهم الدكتور محمد الأشقر والدكتور محمد المرسي زهرة ، ، والدكتور أحمد شوقي ،

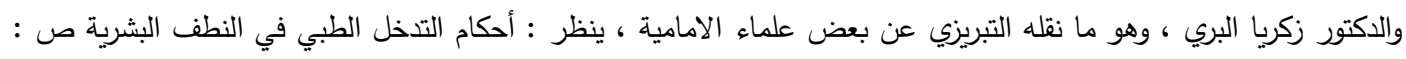

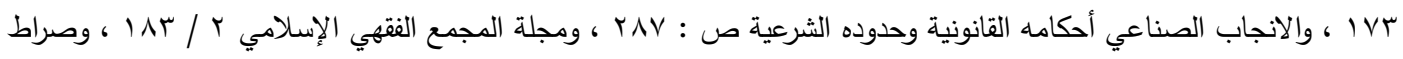

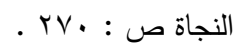

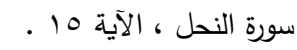

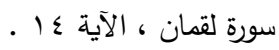

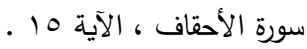

ينظر : دراسات فقهية في قضايا طبية معاصرة ص : • • م ، والاخصاب خارج الجسم ص : 11 11

سورة البقرة ، الآية سبr .

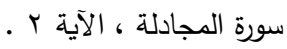




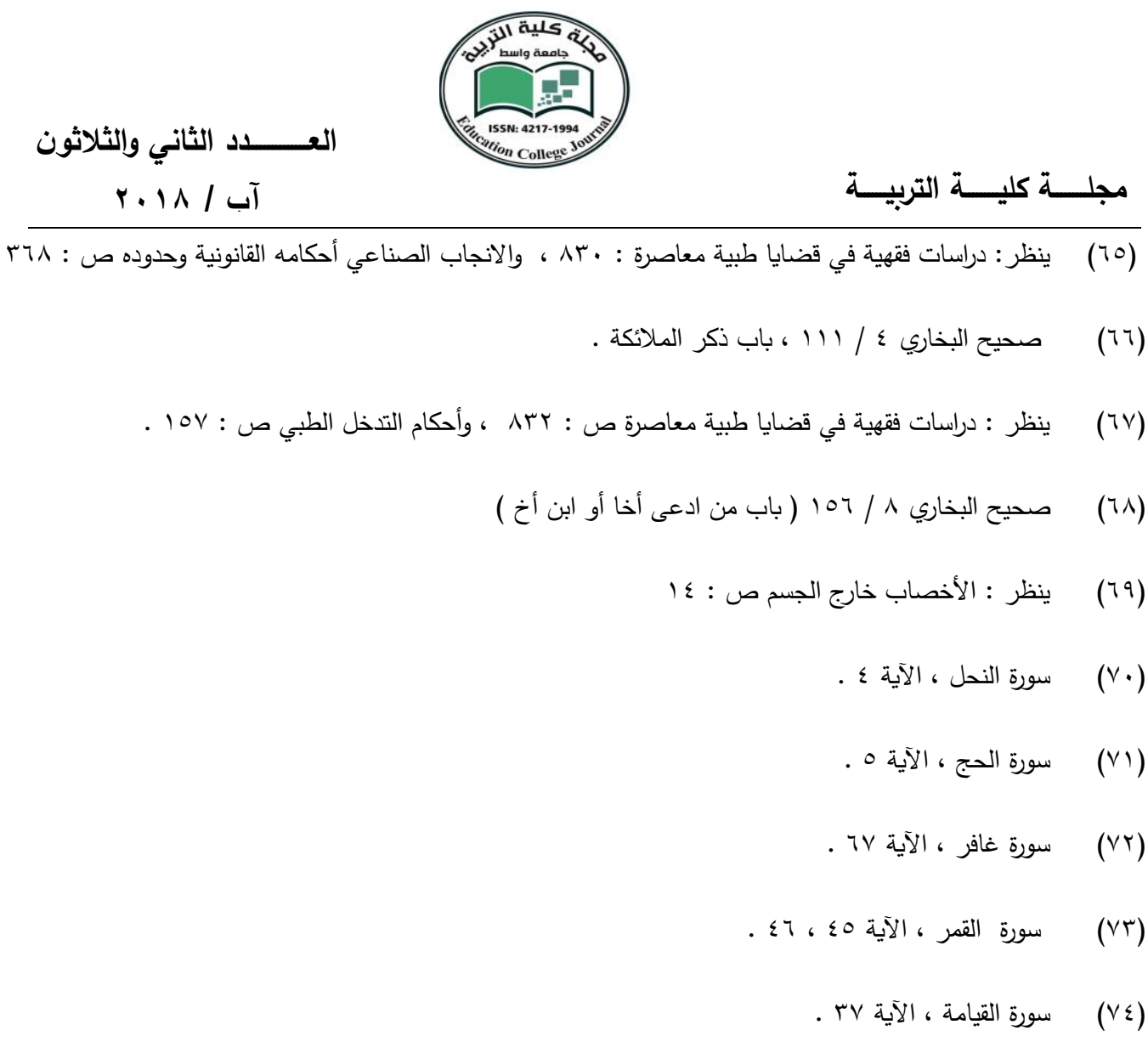

ينظر : المنظور القانوني والثرعي لعقد اجارة الأرحام ص : 0؛ ، للدكتورة ناديا قزمار ، بحث منشور في مجلة

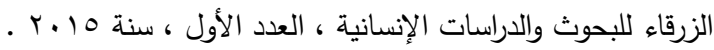

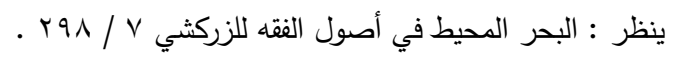

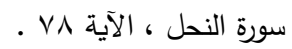

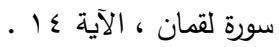$$
\text { سورة الأحقاف ، الآية } 10 \text {. (10. }
$$

$$
\text { ينظر : الاخصاب خارج الجسم ص : با }
$$

ينظر : أحكام التدخل الطبي ص : ج IV ، و دراسات فقهية في قضايا طبية معاصرة ص : بrی . 


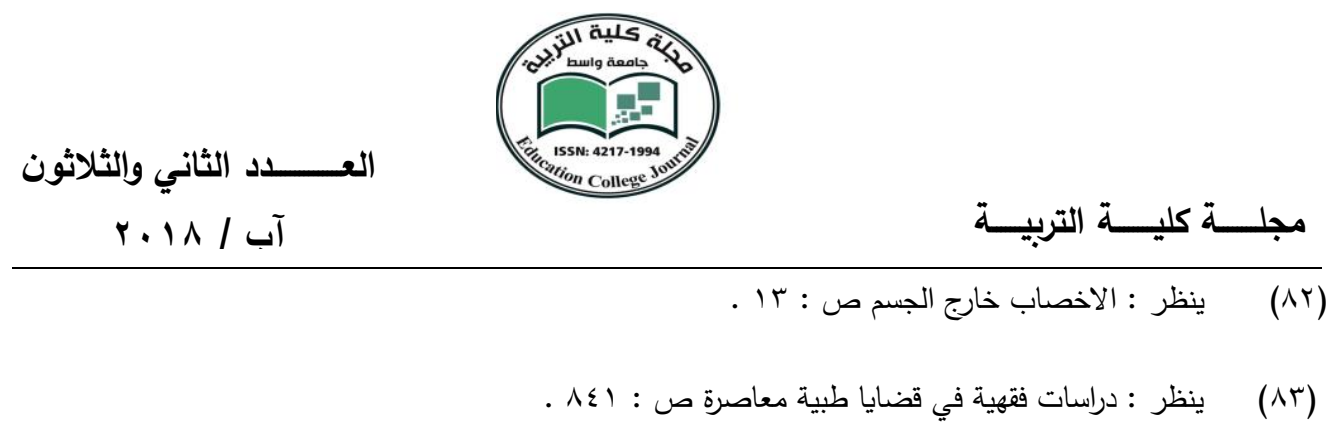

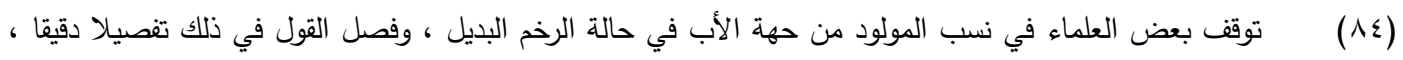

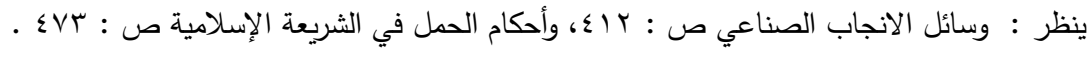

ذهب الى هذا القول علماء المجمع الفقهي الإسلامي المنعقد في مكة المكرمة ، وآخرون منهم الدكتور مصطفى الزرقا

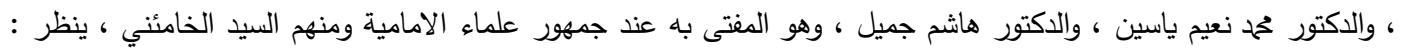

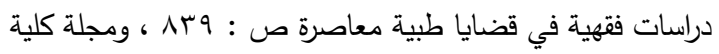

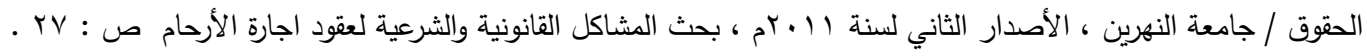
(1) ينظر : الاخصاب خاج الحسم ص : 10 ، والانجاب الصناعي أحكامه القانونية وحدوده الثرعية ص : بهץ .

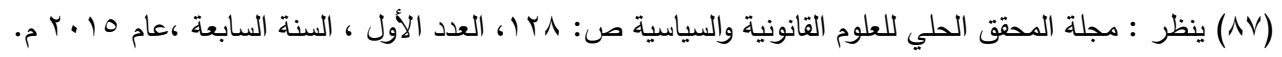
(^^)

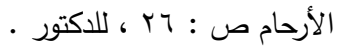

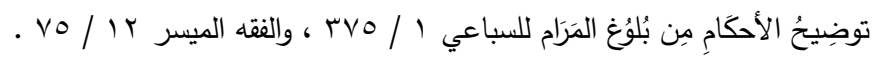
ان الذين ذهبوا الى هذا القول هم الذين قالوا بعدم جواز الحمل عن طريق الرحم البديل ، وهو الذي رجحه

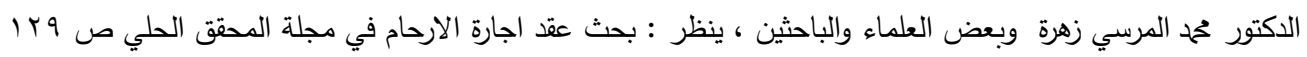

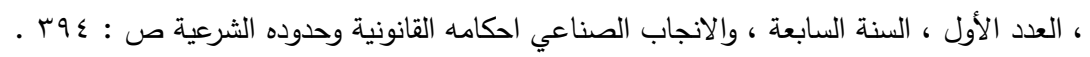

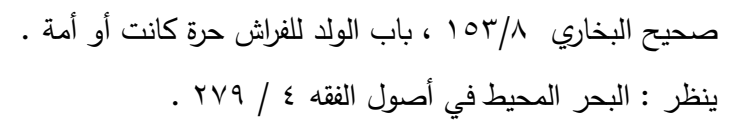




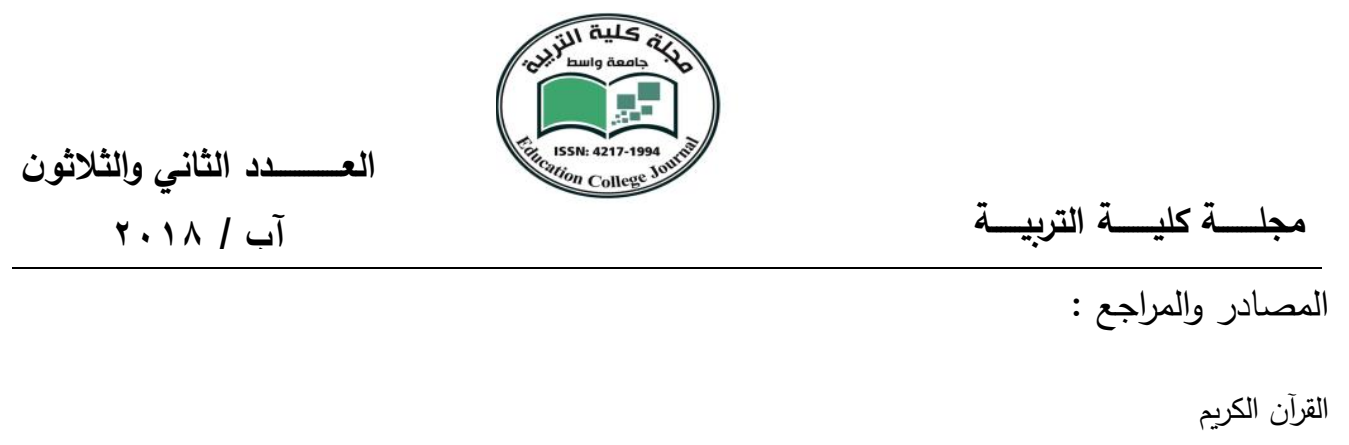

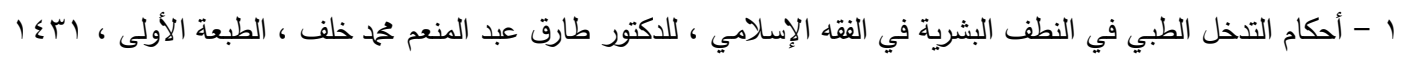

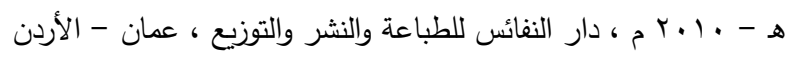

r - احكام الحمل في الثريعة الإسلامية ،للدكتور خالد محمد صالح ، سنة النشر 11 بr م ، دار الكتب القانونية ، القاهرة مصر

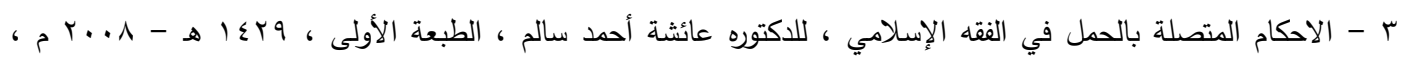

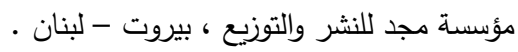

ع - الاستيعاب في معرفة الأصحاب ، لأبي عمر يوسف بن عبد الله بن محم بن عبد البر بن عاصم النمري القرطبي

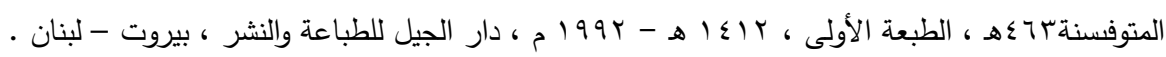

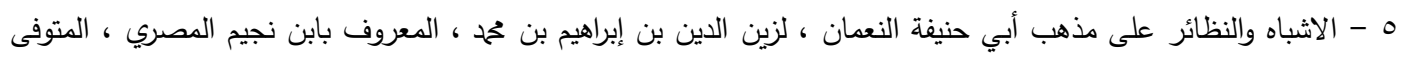

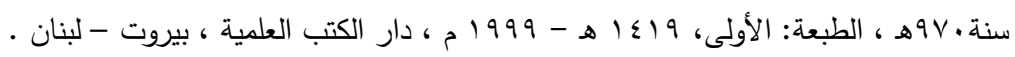

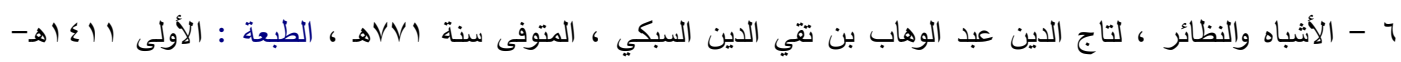

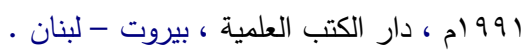

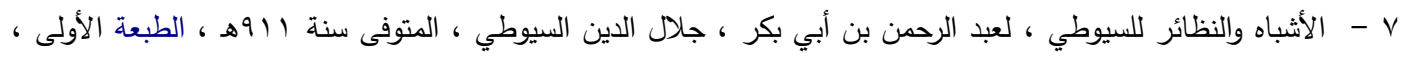

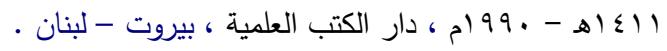

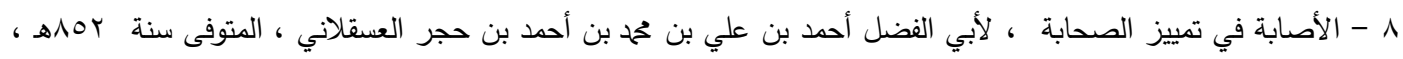

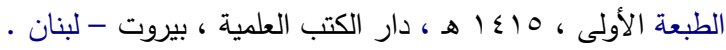

q - الانجاب الصناعي أحكامه القانونية وحدوده الثرعية ، دراسة مقارنة ، للدكتور محم المرسي زهرة ، نشر جامعة الكويت ، . 1994 


\section{العــــــــد الثاني والثلاثون}

آب /

\section{مجلــــة كليـــة التربيـــة}

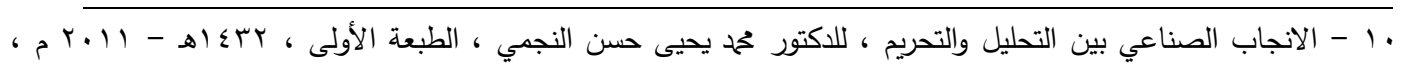

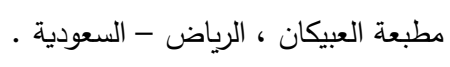

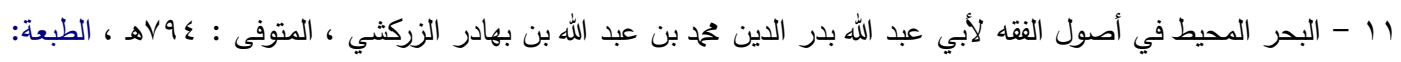

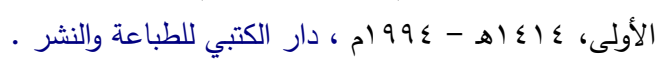

r ا - تحفة المحتاج في شرح المنهاج لأحمد بن محمد بن علي بن حجر الهيتمي ، نشر المكتبة التجارية الكبرى بمصر لصاحبها

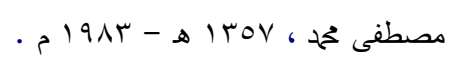

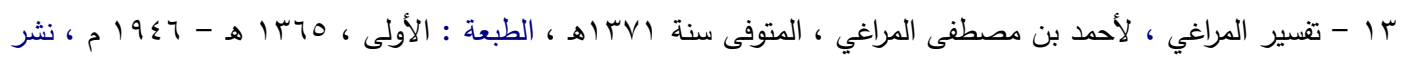

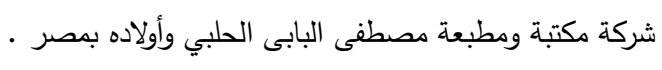

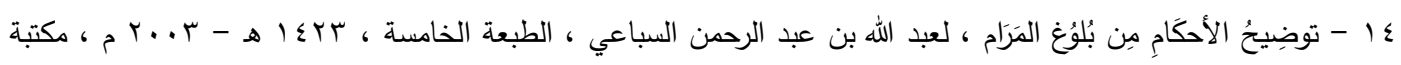

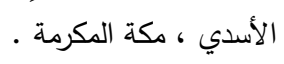

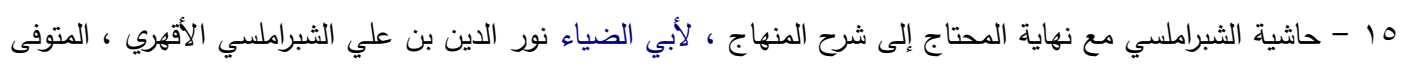

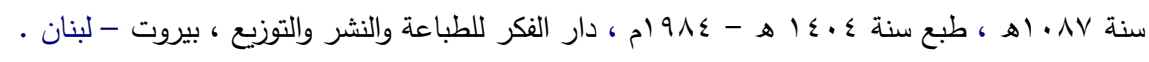

17 ا 17 - دراسات فقهية في قضايا طبية معاصرة ، بحث ( الأم البديلة أو الرحم المستأجر ، رؤية إسلامية ) ، للدكتور عارف علي

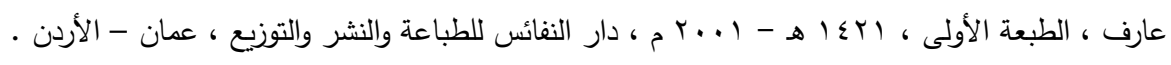

V V الدرر الكامنة في أعيان المائة الثامنة ، لأبي الفضل أحمد بن علي بن محم بن أحمد بن حجر العسقلاني ،المتوفى سنة

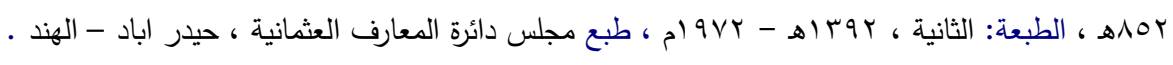

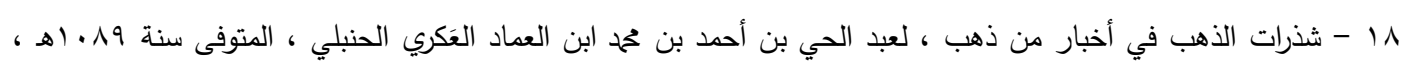

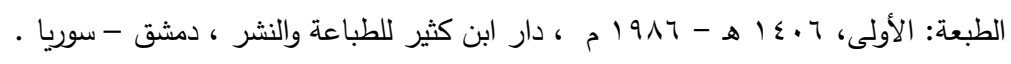

9 1 - صحيح البخاري ، لمحمد بن إسماعيل أبو عبدالله البخاري الجعفي ، الطبعة: الأولى ، بr乏 اهـ نشر دار طوق النجاة .

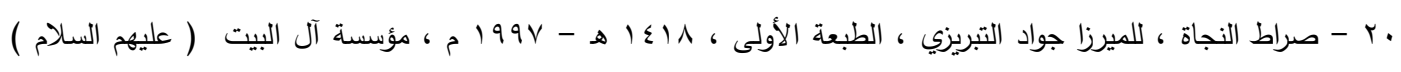
لإحياء التراث 


\section{العـــــــد الثاني والثلاثون}

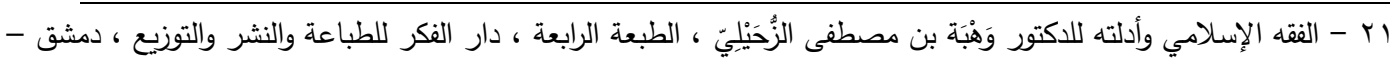
سوريا .

r Y - الفقه الميسر في ضوء الكتاب والسنة ، لمجموعة من المؤلفين ، سنة الطبع ؟r؟ الهـ ، نشر مجمع الملك فهد لطباعة

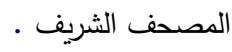

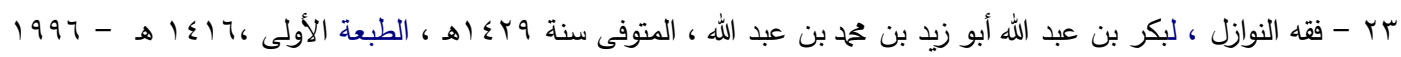

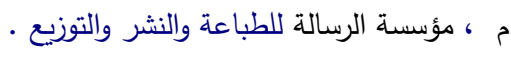

ع r - القواعد ، لزين الدين عبد الرحمن بن أحمد بن رجب بن الحسن، السَلامي، البغدادي، ثم الدمشقي، الحنبلي ، المتوفى سنة

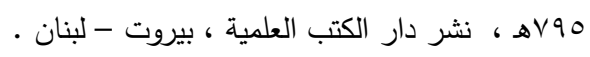

ه ب - مسند ابن أبي شيبة ، لأبي بكر بن أبي شيبة ، عبد الله بن ححمد بن إبراهيم بن عثمان بن خواستي العبسي ، المتوفى سنة

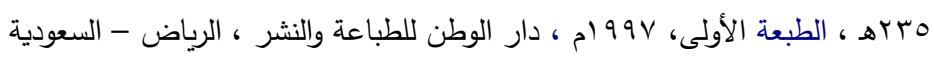

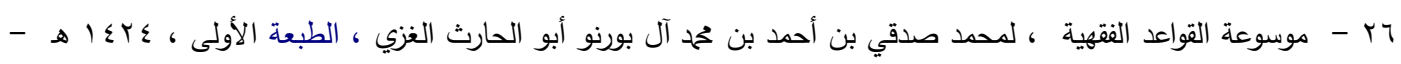

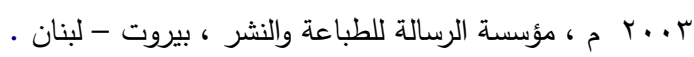

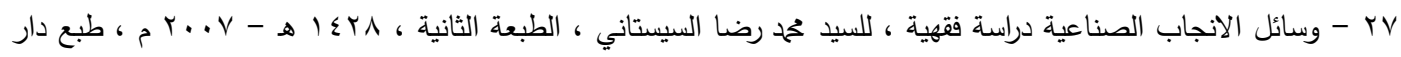

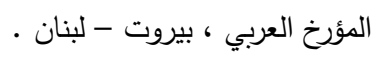

المجلات

ا - اجارة أرحام النساء في الفقه الإسلامي والفقه الوضعي ، للدكتور عبد الله يوسف إبراهيم ، بحث منشور في مجلة جامعة

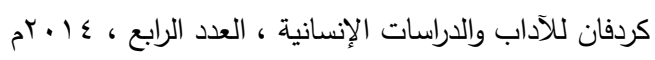

ץ - الاخصاب خارج الجسم مع استئجار الرحم ، للدكتور ماهر حامد الحولي ، مجلة جامعة الأزهر بغزة ، العدد الثاني ، المجلد

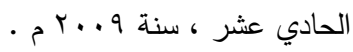

، - تأجيرالأرحام في الفقه الإسلامي ، للدكتورة هند الخولي ، بحث منشور في مجلة جامعة دمشق للعلوم الاقتصادية والقانونية

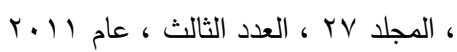




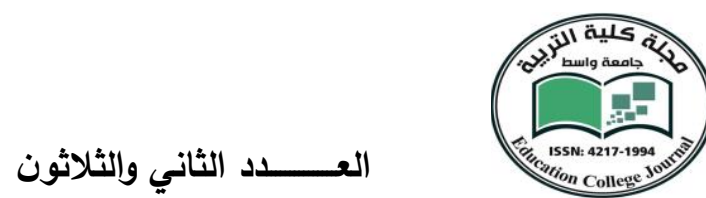

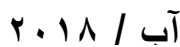

مجلــــة كليـــة التربيــة

ـ - الحمل لحساب الغير في الفقه الإسلامي والقانون المقارن بين الحظر والاباحة ، للدكتور الصادق ضريفي ، مجلة معارف

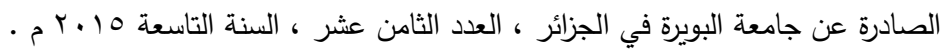

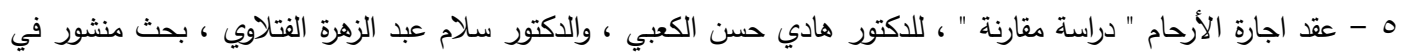

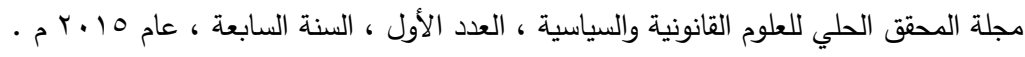
1 - مجلة المجمع الفقهي الإسلامي ، الصادرة عن مجمع الفقه الإسلامي التابع لرابطة العالم الإسلامي .

V - مجلة مجمع الفقه الإسلامي " بحث التلقيح الصناعي وأطفال الأنابيب" ، للدكتور محمد على البار ، بحث منشور في مجلة

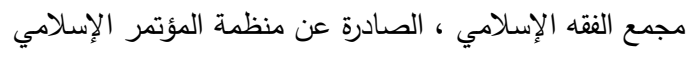

^ - المشاكل القانونية والثرعية لعقود اجارة الأرحام ، للدكتور عقيل فاضل الدهان ، والدكتور رائد صيوان المالكي ، بحث منشور ،

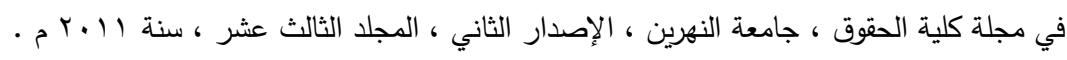

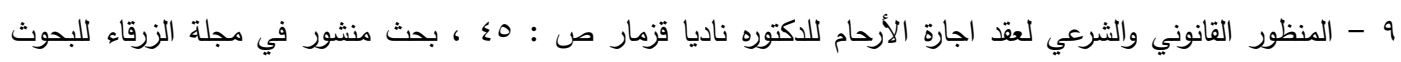

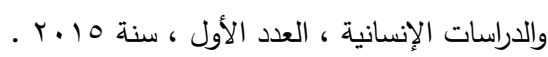

